University of Navarra

\title{
INNOVATION AND THE EXPORT-PRODUCTIVITY LINK
}

\author{
Bruno Cassiman \\ Elena Golovko
}


The Public-Private Center is a Research Center based at IESE Business School. Its mission is to develop research that analyses the relationships between the private and public sectors primarily in the following areas: regulation and competition, innovation, regional economy and industrial politics and health economics.

Research results are disseminated through publications, conferences and colloquia. These activities are aimed to foster cooperation between the private sector and public administrations, as well as the exchange of ideas and initiatives.

The sponsors of the SP-SP Center are the following:

- Accenture

- Ajuntament de Barcelona

- Official Chamber of Commerce, Industry and Navigation of Barcelona

- BBVA

- Diputació de Barcelona

- Garrigues, Abogados y Asesores Tributarios

- Catalan Government (Generalitat de Catalunya)

- Sanofi-Aventis

- Telefonica

- T-Systems

- VidaCaixa

The contents of this publication reflect the conclusions and findings of the individual authors, and not the opinions of the Center's sponsors. 


\title{
INNOVATION AND THE EXPORT-PRODUCTIVITY LINK
}

\author{
Bruno Cassiman* \\ Elena Golovko**
}

\section{Abstract}

In this paper, we explore the relationship between innovation activity, productivity, and exports using a panel of Spanish manufacturing firms for 1990-1998. Our results - based on nonparametric tests - suggest that firm innovation status is critical in explaining the positive export-productivity association documented in prior research. For the sample of small innovating firms, we find no significant differences in productivity levels between exporters and non-exporters. Product innovation in particular seems to explain this positive association between exports and productivity. For small non-innovating firms with low and medium productivity levels, however, exporting firms continue to exhibit higher productivity than nonexporting firms.

* Professor General Management, IESE and K.U. Leuven and CEPR

**PhD Candidate and Research Assistant, IESE

Keywords: Innovation, productivity, exports, industry dynamics. 


\section{INNOVATION AND THE EXPORT-PRODUCTIVITY LINK*}

\section{Introduction}

The dynamic processes of firm formation, growth, prospering, and failure generate a considerable degree of heterogeneity in firm performance, not only across industries, but more interestingly, also within industries (Bartelsman and Doms, 2000).

Most of the theoretical models of industry dynamics assume that firms are born with an inherent ability, their productivity. Efficient firms survive and grow in the market, while inefficient firms, with productivity below a certain threshold, decline and fail (J ovanovic, 1982; Hopenhayn, 1992). These models, however, assume that the productivity distribution across firms is exogenous to firms, thus relating firm survival to luck-of-draw. Firms with low productivity exit, while "lucky" firms with high productivity survive and continue growing. Little room is left for firm decisions, except for the decision on exiting, which is endogenized. The model of Pakes and Ericson (1995) improves on these models by introducing investment decisions that can potentially enhance survival chances.

While theoretically such heterogeneity and dynamics is difficult to handle, empirically it provides a wealth of interesting observations. Nevertheless, we know very little about the connection between individual firm decisions and their dynamic consequences. One of the basic empirical facts related to productivity is a strong positive association between productivity and export activity at the firm level. Most studies explain this pattern by the self-selection of more efficient firms into the export market (Clerides, Lach, et al., 1998; Bernard and Jensen, 1999; Delgado, Farinas, et al., 2002; Fafchamps, El Hamine, et al. 2002), confirming the sunk cost hypothesis that only those firms who are efficient enough to bear the entry costs and intense competition of the export market will start exporting. This suggests that a closer examination of prior firm decisions might be needed to understand this important selection.

In this paper, we take the first step towards explaining the observed productivity-exports link. We argue that a potential underlying mechanism for the selection of more productive firms into exporting is related to firms' innovation. Successful innovation enhances the firm's productivity, leading to the selection of the more productive firms into the export markets. Yet,

\footnotetext{
* We are grateful for the comments received from J osé Manuel Campa and seminar participants at the J ornadas de Economía Industrial in Barcelona and the EARIE conference in Amsterdam. We acknowledge financial support from the Anselmo Rubiralta Center for Globalization and Strategy and the Public-Private Sector (SP-SP) Research Center at IESE Business School, the Steunpunt $O \& O$ at the Catholic University of Leuven, and the Spanish Ministry of Education, Science and Technology for project No SEJ 2006-11833/ECON.
} 
anything affecting its productivity could drive the firm into exports. Recent productivity literature, however, has found evidence that suggests that firm-specific demand variations, rather than technical efficiency, are the dominant factor in determining firm survival and positively influencing productivity (Foster et al., 2005). This suggests that product innovation related to positive demand shocks rather than innovation in processes related to production efficiency could be responsible for the increase in productivity and, consequently, entry into exporting. Consistent with this argument, product innovation has been found to play a very important role in explaining the firm's export decision (Basile, 2001; see related paper Cassiman and Martínez-Ros, 2007), showing that innovation-active firms are significantly more likely to become exporters than non-innovators. Thus, accounting for innovation may be critical in explaining the strong positive correlation between exporting and productivity in the existing research. We therefore argue that the observed productivity-export link may be partly explained by the firm's innovation status.

We examine the relationship between productivity and exports using a panel of Spanish manufacturing firms. We investigate the export-productivity link of the firms that engage in innovation activities and compare the results to those obtained for the non-innovating firms using non-parametric tests. As our findings indicate, innovating firms show no significant difference in productivity levels for exporting and non-exporting groups, suggesting that firm innovation strategy is a very important factor in explaining the exports-productivity association. Our findings have important policy implications. If innovation activity is a source of productivity growth, then policies aimed at promoting innovation, and product innovation in particular, might be more effective than direct export promotions, at least for firms "at risk" for innovating.

The paper proceeds as follows. In Section 2 we discuss the related literature. Sections 3 and 4 describe the data and methodology used in this study. Section 5 presents the results of the empirical analysis. A discussion section concludes.

\section{Related Literature}

In the empirical international trade literature, the positive association between exports and firm productivity has been well-documented. At least two explanations for the observed exportsproductivity link have been suggested. On one hand, the positive association between exporting and productivity is explained through a selection mechanism. Sunk start-up costs associated with becoming an exporter, lead to the self-selection of more productive firms into exporting (Aw, Chen, and Roberts, 1997; Roberts and Tybout, 1997; Bernard and Jensen, 1999, 2004; Clerides, Lach and Tybout, 1998; Delgado, Farinas, et al., 2002; Fafchamps, El Hamine, et al., 2002). The hysteresis in exporting serves as evidence for the sunk entry costs in the export market. On the other hand, there is the possibility of learning-by-exporting - exporters may learn from their foreign contacts, adopting new production technologies and increasing productivity (Aw, Chung and Roberts, 2000; Delgado, Farinas, et al. 2002).

With both mechanisms being plausible, empirical evidence is rather unanimous in supporting the selection hypothesis behind the exports-productivity link (Roberts and Tybout, 1997; Clerides, Lach and Tybout, 1998; Bernard and Jensen, 1999; Delgado, Farinas, et al. 2002; Fafchamps, El Hamine, et al., 2002). The general finding is that exporting firms have higher 
productivity than non-exporters before taking up exports and no significant productivity advantages are observed between continuous exporters and non-exporting firms over time.

Such heterogeneity in productivity raises an important question about the sources of these exporting firms' high productivity. How do firms obtain higher productivity levels that allow them to easily enter the export markets? International trade literature, following the work on industry dynamics (Jovanovic, 1982; Hopenhayn, 1992), has attempted to incorporate firm heterogeneity in international trade modeling. Recent theoretical work by Melitz (2003) and Bernard et al. (2003) formulates the theories that reflect the empirical regularities observed in export behavior and productivity. In these theories, a firm's initial productivity level is determined by a random draw from a certain distribution function. The model by Melitz (2003) assumes sunk entry costs in the export market, while Bernard et al. (2003) assume Bertrand competition among producers, which only allows the most productive firms to incur trading costs associated with exports. Thus, these theories demonstrate the selection mechanism of more productive firms into the export market. The models, however, do not explain why these firms are more productive and self-select into exporting, that is, the theories are not causal theories between firm decisions and a decision to export.

One important source of productivity differences seems to be related to R\&D and innovation activities. A number of empirical studies have documented the positive and significant effect of R\&D and innovation on firm productivity and productivity growth. Crepon et al. (1998), estimating a structural model that links productivity, innovation output and innovation inputs, find that firm productivity correlates positively with higher innovation output. In line with their result, Jefferson et al. (2002) for Chinese firms show that new product sales are positively associated with productivity. Using the panel of Spanish firms, Huergo and Jaumandreu (2004) find that process innovation is an important determinant of productivity growth at the firm level. Investigating the relationship between innovation and productivity in four European countries, Griffith et al. (2005) find results, consistent with the previous studies, that both product and process innovations have a positive significant effect on firm-level productivity in three out of the four countries.

At the same time, R\&D and innovation activities seem to play a very important role in explaining firm's decision to export and export volumes. In particular, recent studies find that innovation is a very important driver of the export decision. For a sample of Italian manufacturing firms, Basile (2001) shows that firms introducing product and/or process innovations either through $R \& D$ or through investments in new capital are more likely to export. Bernard and J ensen (2004) find that changing primary SIC code - which could indicate the introduction of new products - significantly increases the probability of entering export markets. In a related paper, Cassiman and Martínez-Ros (2007) find a strong positive effect of product innovation on a firm's decision to export.

Taken together, prior empirical findings suggest that innovation activity may be responsible for both the productivity enhancement and export orientation of a firm and explain the correlation between exports and productivity. A number of studies provide empirical results going in the direction of our argument. Aw and Batra (1998), on a sample of Taiwanese firms, find that for the group of large, high-technology firms, exporters do not differ from non-exporters in their efficiency levels. However, in the group of small firms with no formal investments in technology, exporters are significantly closer to the production frontier than non-exporting firms. Using the sample of Spanish firms, Delgado et al. (2002) show that the exportproductivity link varies depending on firm size. They observe no significant difference in 
productivity levels between exporters and non-exporters for large firms. However, for small firms, exporters show significantly higher productivity levels than non-exporters. In a recent paper, A w et al. (2005) find that for firms that do not invest in R\&D, the exporters' productivity is significantly higher than that of non-exporting firms. Moreover, firms that export and invest in R\&D are found to have higher productivity than those that only export. This evidence is used to argue that not only do more efficient firms select into the export market, but exports and R\&D are important and complementary sources of productivity growth, with R\&D activities facilitating the benefits from export markets. When coupled with the well-documented positive link between innovation and firm size (although possibly at a decreasing rate), these findings point to the importance of innovation as an explanatory variable driving the exportproductivity link.

Therefore, connecting innovation, productivity and exports, we argue that accounting for innovation might take us some way in explaining the positive association between exports and productivity. Furthermore, in a recent paper, Foster et al. (2005) find that firm-specific demand shocks rather than production efficiency shocks explain differences in productivity, suggesting that product innovation rather than process innovation improves productivity, and, consequently, drives the decision to export.

\section{Data}

The data that are used in this study come from a survey of Spanish manufacturing firms started in 1990 with data collected annually up to 1998. The project was conducted by the Fundación Empresa Pública with financial support from the Spanish Ministry of Science and Technology. The information collected each year is consistent with the information in the previous years. The sample contains the population of firms with at least 200 employees and $4 \%$ of the population of firms with more than 10 and less than 200 employees. Firms that dropped out of the original sample are replaced every year by firm with the similar characteristics from the population. The survey contains detailed information for every year on exporting and innovation activities, reporting among other questions information on export volume and on product and process innovation carried out by a firm. ${ }^{1}$

The initial sample includes 2188 firms in 1990 and 3195 firms in 1998. The dataset contains firms from 20 distinct industries and is representative of the Spanish manufacturing sector. Due to entry, exit, and missing values, the resulting sample includes 11,855 firm-year observations. The sample is an unbalanced panel, with a significant variation in the export and innovation behavior across firms as well as over time. Previous research [Delgado et al. (2002); Campa (2004); Huergo and J aumandreu (2004); Cassiman and Martínez-Ros (2007), among others] has used the same data set as it is representative for the Spanish manufacturing sector.

\section{Empirical Strategy and Methods}

Our empirical strategy is as follows. We start by reproducing the results existing in the literature and identify the positive association between productivity and export status in our sample. Next, we compare the productivity levels of innovating versus non-innovating firms in

\footnotetext{
${ }^{1}$ The definitions of product and process innovation as they appear in the questionnaire are provided in Appendix.
} 
order to show that innovation activity adds to firm productivity. Finally, we check whether the differences in the productivity of exporters and non-exporters persist when firm innovation status is taken into account.

\section{Productivity Measure}

To measure productivity we construct an index of total factor productivity for each firm, using a multilateral index developed by Caves et al. (1982) and extended by Good et al. (1997). ${ }^{2}$ The TFP index is calculated as the logarithm of the firm's output less a cost-share weighted sum of the logarithms of the firm inputs. To make the comparison between any two firm-year observations possible, each firm's outputs and inputs are calculated as deviations from a reference firm. The reference firm is a hypothetical firm that varies across industries with input cost-based shares computed as an arithmetic mean of cost shares over all observations, and outputs and inputs computed as the geometric mean of outputs and inputs over all observations. Moreover, since the sampling proportions in our data are different for small ( $\leq 200$ employees) and large firms (> 200 employees), the reference firm also varies across size groups. Thus, each firm's output, inputs and productivity for each year are measured relative to this hypothetical firm in the same size group (small or large) and industry. For more detail on the computation of the TFP index, see Appendix.

\section{Methods}

We start with the graphical description of the TFP distributions of exporting versus nonexporting, and innovating versus non-innovating firms across 1991-1998. In our analysis, we focus only on the small firms ( $\leq 200$ employees), since the number of large firms in our sample is not sufficient for the test to be statistically conclusive.

Next, we conduct a number of tests to document the expected effects formally. We begin by comparing means and variances of the TFP level distributions of exporters and non-exporters. Then we compare the productivity distributions themselves across these two subsamples of firms. To test the differences in the TFP level distributions of exporters versus non-exporters, we employ a Kolmogorov-Smirnov equality-of-distributions test, used recently in Delgado et al. (2002). This non-parametric test rejects the null hypothesis of samples coming from the same populations if there is a point for which the cumulative empirical distributions of two independent samples are significantly different. The testing procedure is based on the concept of first-order stochastic dominance. Let $F$ and $G$ be cumulative distribution functions of TFP for two subsamples to be compared (in our case, e.g. exporters versus non-exporters). First-order stochastic dominance of $F$ relative to $G$ is defined as: $F(z)-G(z) \leq 0$ uniformly for any $z$ from $R$, with strict inequality for at least one $z$. In order to show that $F$ stochastically dominates $G$ we need to conduct the following tests:

-two-sided test : Ho: $F(z)-G(z)=0$ for all $z$ from $R$ versus $H a: F(z)-G(z) \neq 0$ for some $z$;

- one-sided test: Ho: $F(z)-G(z) \leq 0$ for all $z$ from $R$ versus $H a: F(z)-G(z)>0$ for some $z$.

\footnotetext{
${ }^{2}$ Our method of calculating the TFP index is similar to that performed in Aw et al. (2000) and Delgado et al. (2002).
} 
The two-sided test checks the hypothesis on the equality of the distributions $F$ and $G$. The distributions $F$ and $G$ are not significantly different if we cannot reject Ho for the two-sided test. The one-sided test allows determining whether one distribution dominates the other. Not being able to reject $\mathrm{Ho}$ for the one-sided test will mean that $\mathrm{F}$ is equal or to the right of the distribution $\mathrm{G}$.

Thus, in order to show that $F$ stochastically dominates $G$ we have to demonstrate that the null hypothesis Ho for the two-sided test can be rejected, while Ho for the one-sided test cannot be rejected. This will be consistent with $F$ being to the right of $G$. In our case, it will imply that the TFP level distribution of exporters stochastically dominates the distribution of TFP for nonexporters. We conduct the Kolmogorov-Smirnov test for each time period $t, t=1991, \ldots, 1998$.

Next, we compare the productivity levels of innovators and non-innovators using the same battery of tests. We repeat the same tests for the exporting and non-exporting groups accounting for firms' innovation strategy. Finally, we run quantile regressions of productivity levels on export variable and several controls in order to investigate differences in the TFP levels of exporters and non-exporters in more detail.

We define exporters as firms exporting in the current year. Non-exporters are those firms that did not perform exports in the current year. Innovation activity is measured in several ways. We distinguish between innovating in product and in process, using two dummies that indicate whether a firm carried out a product or a process innovation. Next, we employ a dummy variable that indicates whether a firm has performed any innovation activity (either product or process). Finally, we use a measure for the innovation input - whether a firm invested in R\&D. We measure our innovation variables with a one-year lag, since innovation is unlikely to drive the productivity improvements in the same year. ${ }^{3}$

\section{Results}

We start with the graphical representation of the cumulative distribution functions of TFP levels for the different groups of firms, looking at the productivity distributions of 1 ) exporting versus non-exporting firms; 2) innovating versus non-innovating firms; and 3) exporters versus nonexporters for the innovating and non-innovating groups.

Figures 1-5 present the results for these subsamples of firms. The distribution of performers (exporters or innovators) lies to the right of the distribution of non-performers, which suggests first-order stochastic dominance. The exception is the process innovation case, for which TFP level distributions of innovating and non-innovating firms seem to coincide. Figures 6-9 compare the productivity distributions of exporters and non-exporters in the groups of innovators and non-innovators. For the non-innovating firms, the TFP distribution of exporters is clearly to the right of that of non-exporters, which points to stochastic dominance. In the group of innovating firms the difference between TFP distributions is not so evident, especially for the product innovation case. Overall, the visual comparison of the TFP level distributions shows that the productivity distribution of exporters dominates that of non-exporters, which

\footnotetext{
${ }^{3}$ See Appendix for the description of the variables.
} 
also holds in the group of non-innovators. For innovating firms, however, the difference is less pronounced, hinting at the existence of the hypothesized effect of innovation activity on productivity and export decision. In the following, we perform a formal comparison of TFP level distributions.

\subsection{Exporters Versus Non- Exporters}

First, we formally document the existence of the positive association between export orientation and firm productivity in line with prior research.

Table 1 lists the results for tests on means and variances and the Kolmogorov-Smirnov test for exporters and non-exporters.

\section{Exporting Versus Non-Exporting Firms}

\section{Table 1}

Difference in TFP Level Distributions Between Exporters and Non-Exporters

\begin{tabular}{|c|c|c|c|c|c|c|c|c|c|c|c|}
\hline & \multicolumn{2}{|c|}{$\begin{array}{c}\text { Number of } \\
\text { firms }\end{array}$} & \multirow[t]{2}{*}{$\begin{array}{l}\text { Diffe- } \\
\text { rence in } \\
\text { means }\end{array}$} & \multicolumn{2}{|c|}{$\begin{array}{l}\text { Mean (non- } \\
\text { exporters)> mean } \\
\text { (exporters) }\end{array}$} & \multicolumn{2}{|c|}{$\begin{array}{c}\text { Variance (non- } \\
\text { exporters)> } \\
\text { variance } \\
\text { (exporters) }\end{array}$} & \multicolumn{2}{|c|}{$\begin{array}{l}\text { K-S test for } \\
\text { equality of } \\
\text { distributions* }\end{array}$} & \multicolumn{2}{|c|}{$\begin{array}{l}\text { Difference in } \\
\text { favor of } \\
\text { exporters }\end{array}$} \\
\hline & $\exp =1$ & $\exp =0$ & & t-statistic & $\mathrm{P}$-value & F-statistic & P-value & $\mathrm{D}$ & P-value & $\mathrm{D}$ & P-value \\
\hline 1991 & 295 & 591 & -0011 & -0694 & 0.244 & 433 & $\overline{99}$ & 067 & 3 & 032 & 66 \\
\hline 1992 & 378 & 6 & -0.030 & -2.067 & 0.019 & 1.320 & 0.998 & 0.104 & 0.009 & -0.025 & 0.752 \\
\hline 1993 & 3 & 6 & & -3.809 & 0.0 & 1.425 & 0. & 0.1 & 0. & -0.004 & 0.993 \\
\hline 1994 & 439 & 586 & -0.044 & -3.371 & 0.000 & 0.974 & 0.384 & 0.124 & 0.001 & -0.008 & 0.964 \\
\hline 1995 & 449 & 504 & -0.059 & -4.271 & 0.000 & 1.046 & 0.690 & 0.132 & 0.000 & -0.001 & 1.000 \\
\hline 1996 & 483 & 532 & -0.057 & -4.176 & 0.000 & 1.074 & 0.787 & 0.174 & 0.000 & -0.007 & 0.975 \\
\hline 1997 & 616 & 585 & -0.073 & -5.809 & 0.000 & 1.188 & 0.982 & 0.169 & 0.000 & 0.000 & 1.000 \\
\hline 1998 & 573 & 528 & -0.067 & -5.076 & 0.000 & 1.490 & 1.000 & 0.142 & 0.000 & -0.002 & 0.997 \\
\hline
\end{tabular}

* Here and further on, we test the following two hypotheses:

Ho(1): $F(T F P$ group 1$)=F(T F P$ group2) - the test for the equality of distributions;

Ho(2): F(TFP group1)<F(TFP group2) - the test for the differences in TFP levels favorable to group1, where group1 and group2 are the groups of exporting and non-exporting (or innovating and non-innovating) firms, respectively.

The third and the fourth columns report the difference in means and the test statistic on the null hypothesis that the mean TFP level of non-exporting firms is significantly higher than the mean TFP level of exporting firms. The comparison of average TFP levels indicates that exporting firms have higher levels of TFP than non-exporters, with the difference being statistically significant.

The significance of the results, however, varies across years. During 1991-1998, Spain underwent the entire business cycle, with a slowdown in the economy starting in 1991, a sharp recession in 1993 - beginning of 1994, and a recovery in 1995-1998. The unfavorable economic conditions in the early nineties might be responsible for the non-significance of test 
statistics when comparing the TFP distributions of exporters/non-exporters and innovators/non-innovators. ${ }^{4}$

Column five presents the test statistic for the hypothesis of greater variability of TFP level for non-exporting firms than for exporting ones. In most cases, we cannot reject the hypothesis that the variance of TFP levels of non-exporting firms is larger than that of exporters

Columns six and seven report the results for the Kolmogorov-Smirnov test - the statistic for the two-sided test on the equality of distributions and the one-sided test results. We can reject the null hypothesis of equality of distributions for exporters and non-exporters at $1 \%$ significance level. In the one-sided test, the null hypothesis states that the TFP distribution of exporters stochastically dominates the TFP distribution of non-exporters. As the results in column 7 show, the null hypothesis for the one-sided test, i.e. that the TFP level differences are in favor of exporters, cannot be rejected.

Therefore, the results in Table 1 confirm the findings of the prior studies for our sample, showing that firm export status is indeed associated with higher productivity levels. Exporting firms not only show higher levels of TFP, but the distributions of TFP for exporters and nonexporters are significantly different, with the exporters' TFP distribution stochastically dominating the non-exporters' TFP distribution.

\subsection{Innovators Versus Non- Innovators}

We further explore the differences in productivity levels between innovating and noninnovating firms. Table $2 A-D$ lists the results for product and process innovation variables, as well as for innovation and R\&D dummies.

\section{Innovating Versus Non- Innovating Firms}

\section{Table 2A}

Difference in TFP Level Distributions Between Firms with Product Innovation and Firms with No Innovation

\begin{tabular}{|c|c|c|c|c|c|c|c|c|c|c|c|}
\hline & \multicolumn{2}{|c|}{$\begin{array}{c}\text { Number of } \\
\text { firms }\end{array}$} & \multirow[t]{2}{*}{$\begin{array}{l}\text { Diffe- } \\
\text { rence } \\
\text { in } \\
\text { means }\end{array}$} & \multicolumn{2}{|c|}{$\begin{array}{c}\text { Mean (no } \\
\text { innovation)> } \\
\text { mean (prod. } \\
\text { innovation) }\end{array}$} & \multicolumn{2}{|c|}{$\begin{array}{c}\text { Variance (no } \\
\text { innovation)> } \\
\text { variance (prod. } \\
\text { innovation) }\end{array}$} & \multicolumn{2}{|c|}{$\begin{array}{l}\text { K-S test for } \\
\text { equality of } \\
\text { distributions }\end{array}$} & \multicolumn{2}{|c|}{$\begin{array}{l}\text { Difference in } \\
\text { favor of firms } \\
\text { with prod. } \\
\text { innovation }\end{array}$} \\
\hline & $\begin{array}{l}\text { Prod. } \\
\text { inno- } \\
\text { vation }\end{array}$ & $\begin{array}{l}\text { No } \\
\text { inno- } \\
\text { vation }\end{array}$ & & t-statistic & P-value & F-statistic & P-value & $\mathrm{D}$ & P-value & $\mathrm{D}$ & $P$-value \\
\hline & & & & & & & & & & & \\
\hline 1991 & 60 & 689 & -0.032 & -1.099 & 0.136 & 1.128 & 0.713 & 0.127 & 0.284 & -0.050 & 0.757 \\
\hline 1992 & 90 & 588 & -0.016 & -0.603 & 0.274 & 1.437 & 0.983 & 0.110 & 0.252 & -0.029 & 0.879 \\
\hline 1993 & 98 & 558 & -0.019 & -0.812 & 0.209 & 1.331 & 0.959 & 0.119 & 0.155 & -0.050 & 0.658 \\
\hline 1994 & 109 & 593 & -0.046 & -2.095 & 0.018 & 1.240 & 0.916 & 0.155 & 0.017 & -0.031 & 0.835 \\
\hline 1995 & 100 & 587 & -0.055 & -2.363 & 0.009 & 1.116 & 0.747 & 0.131 & 0.082 & -0.012 & 0.976 \\
\hline 1996 & 109 & 558 & -0.050 & -2.177 & 0.015 & 1.164 & 0.834 & 0.146 & 0.031 & -0.007 & 0.992 \\
\hline 1997 & 103 & 605 & -0.044 & -1.858 & 0.032 & 1.167 & 0.832 & 0.133 & 0.069 & -0.009 & 0.986 \\
\hline 1998 & 121 & 657 & -0.036 & -1.702 & 0.044 & 1.191 & 0.882 & 0.110 & 0.139 & -0.021 & 0.915 \\
\hline
\end{tabular}

\footnotetext{
4 In general, we observe non-significant results for the early 90's, while testing the differences in the TFP distributions for both export and innovation variables. However, we still observe lower productivity levels in the groups of non-performers.
} 


\section{Table 2B}

Difference in TFP Level Distributions Between Firms with Process Innovation and Firms with No Innovation

\begin{tabular}{|c|c|c|c|c|c|c|c|c|c|c|c|}
\hline & \multicolumn{2}{|c|}{$\begin{array}{c}\text { Number of } \\
\text { firms }\end{array}$} & \multirow[t]{2}{*}{$\begin{array}{l}\text { Diffe- } \\
\text { rence } \\
\text { in } \\
\text { means }\end{array}$} & \multicolumn{2}{|c|}{$\begin{array}{c}\text { Mean (no } \\
\text { innovation)> } \\
\text { mean (proc. } \\
\text { innovation) }\end{array}$} & \multicolumn{2}{|c|}{$\begin{array}{c}\text { Variance (no } \\
\text { innovation)> } \\
\text { variance (proc. } \\
\text { innovation) }\end{array}$} & \multicolumn{2}{|c|}{$\begin{array}{l}\text { K-S test for } \\
\text { equality of } \\
\text { distributions }\end{array}$} & \multicolumn{2}{|c|}{$\begin{array}{l}\text { Difference in } \\
\text { favor of firms } \\
\text { with proc. } \\
\text { innovation }\end{array}$} \\
\hline & $\begin{array}{l}\text { Proc. } \\
\text { inno- } \\
\text { vation }\end{array}$ & $\begin{array}{l}\text { No } \\
\text { inno- } \\
\text { vation }\end{array}$ & & t-statistic & P-value & F-statistic & P-value & $D$ & P-value & $D$ & P-value \\
\hline 1991 & 41 & 689 & 0.028 & 0.815 & 0.792 & 1.086 & 0.612 & 0.114 & 0.626 & -0.114 & 0.365 \\
\hline 1992 & 165 & 588 & -0.002 & -0.109 & 0.457 & 1.207 & 0.927 & 0.050 & 0.887 & -0.050 & 0.528 \\
\hline 1993 & 143 & 558 & -0.004 & 0.227 & 0.589 & 1.328 & 0.979 & 0.053 & 0.882 & -0.053 & 0.524 \\
\hline 1994 & 159 & 593 & 0.010 & 0.543 & 0.706 & 1.107 & 0.779 & 0.088 & 0.255 & -0.088 & 0.146 \\
\hline 1995 & 153 & 587 & -0.014 & -0.717 & 0.237 & 0.862 & 0.116 & 0.126 & 0.034 & -0.033 & 0.765 \\
\hline 1996 & 151 & 558 & -0.019 & -0.926 & 0.177 & 1.105 & 0.768 & 0.102 & 0.143 & -0.033 & 0.775 \\
\hline 1997 & 151 & 605 & -0.021 & -1.053 & 0.146 & 1.382 & 0.992 & 0.094 & 0.206 & -0.015 & 0.948 \\
\hline 1998 & 205 & 657 & -0.009 & -0.503 & 0.308 & 0.741 & 0.003 & 0.063 & 0.522 & -0.032 & 0.730 \\
\hline
\end{tabular}

\section{Table 2C}

Difference in TFP Level Distributions Between Firms with Innovation (Either Product or Process) and Firms with No Innovation

\begin{tabular}{|c|c|c|c|c|c|c|c|c|c|c|c|}
\hline & \multicolumn{2}{|c|}{$\begin{array}{l}\text { Number of } \\
\text { firms }\end{array}$} & \multirow[t]{2}{*}{$\begin{array}{l}\text { Diffe- } \\
\text { rence } \\
\text { in } \\
\text { means }\end{array}$} & \multicolumn{2}{|c|}{$\begin{array}{c}\text { Mean (no } \\
\text { innovation)> } \\
\text { mean (innovation) }\end{array}$} & \multicolumn{2}{|c|}{$\begin{array}{c}\text { Variance (no } \\
\text { innovation)> } \\
\text { variance } \\
\text { (innovation) }\end{array}$} & \multicolumn{2}{|c|}{$\begin{array}{l}\text { K-S test for } \\
\text { equality of } \\
\text { distributions }\end{array}$} & \multicolumn{2}{|c|}{$\begin{array}{c}\text { Difference in } \\
\text { favor of firms } \\
\text { with innovation }\end{array}$} \\
\hline & $\begin{array}{l}\text { Inno- } \\
\text { vation }\end{array}$ & $\begin{array}{l}\text { No } \\
\text { inno- } \\
\text { vation }\end{array}$ & & t-statistic & P-value & F-statistic & $\mathrm{P}$-value & $D$ & $P$-value & $\mathrm{D}$ & P-value \\
\hline & & & & & & & & & & & \\
\hline 1991 & 160 & 689 & -0.028 & 0.814 & 0.066 & 1.262 & 0.963 & 0.095 & 0.161 & -0.031 & 0.779 \\
\hline 1992 & 372 & 588 & -0.015 & -1.083 & 0.139 & 1.306 & 0.997 & 0.071 & 0.172 & -0.016 & 0.889 \\
\hline 1993 & 348 & 558 & -0.005 & -0.362 & 0.358 & 1.259 & 0.990 & 0.055 & 0.494 & -0.043 & 0.439 \\
\hline 1994 & 372 & 594 & -1.444 & -.020 & 0.074 & 1.157 & 0.938 & 0.057 & 0.402 & -0.019 & 0.844 \\
\hline 1995 & 361 & 588 & -0.029 & -2.011 & 0.022 & 1.012 & 0.549 & 0.108 & 0.008 & -0.016 & 0.883 \\
\hline 1996 & 351 & 558 & -0.024 & -1.667 & 0.047 & 1.103 & 0.843 & 0.089 & 0.055 & -0.021 & 0.826 \\
\hline 1997 & 342 & 604 & -0.031 & -2.139 & 0.016 & 1.252 & 0.989 & 0.103 & 0.016 & -0.006 & 0.981 \\
\hline 1998 & 443 & 657 & -0.026 & -2.020 & 0.021 & 0.961 & 0.325 & 0.085 & 0.037 & -0.008 & 0.967 \\
\hline & & & & & & & & & & & \\
\hline
\end{tabular}

\section{Table 2D}

Difference in TFP Level Distributions Between Firms with R\&D and Firms with No R\&D

\begin{tabular}{|c|c|c|c|c|c|c|c|c|c|c|c|}
\hline & \multicolumn{2}{|c|}{$\begin{array}{c}\text { Number of } \\
\text { firms }\end{array}$} & \multirow[t]{2}{*}{$\begin{array}{c}\text { Diffe- } \\
\text { rence } \\
\text { in } \\
\text { means }\end{array}$} & \multicolumn{2}{|c|}{$\begin{array}{c}\text { Mean }(R \& D=0)>> \\
\text { mean }(R \& D=1)\end{array}$} & \multicolumn{2}{|c|}{$\begin{array}{c}\text { Variance }(R \& D=0)> \\
\text { variance }(R \& D=1)\end{array}$} & \multicolumn{2}{|c|}{$\begin{array}{l}\text { K-S test for } \\
\text { equality of } \\
\text { distributions }\end{array}$} & \multicolumn{2}{|c|}{$\begin{array}{l}\text { Difference in } \\
\text { favor of firms } \\
\text { with R\&D }\end{array}$} \\
\hline & $\begin{array}{r}R \& D \\
=1\end{array}$ & $\begin{array}{r}\mathrm{R} \& \mathrm{D} \\
=0\end{array}$ & & t-statistic & P-value & F-statistic & P-value & $\mathrm{D}$ & $\mathrm{P}$-value & $\mathrm{D}$ & P-value \\
\hline & & & & & & & & & & & \\
\hline 1991 & 144 & 705 & -0.021 & -1.099 & 0.136 & 1.047 & 0.627 & 0.130 & 0.027 & -0.015 & 0.951 \\
\hline 1992 & 198 & 762 & -0.029 & -1.615 & 0.053 & 1.417 & 0.998 & 0.115 & 0.024 & -0.020 & 0.885 \\
\hline 1993 & 185 & 721 & -0.023 & -1.371 & 0.085 & 1.452 & 0.999 & 0.092 & 0.140 & -0.039 & 0.633 \\
\hline 1994 & 206 & 759 & -0.028 & -1.715 & 0.043 & 1.012 & 0.533 & 0.076 & 0.273 & -0.006 & 0.989 \\
\hline 1995 & 204 & 745 & -0.035 & -2.059 & 0.019 & 1.303 & 0.989 & 0.116 & 0.021 & -0.017 & 0.915 \\
\hline 1996 & 181 & 729 & -0.045 & -2.469 & 0.007 & 1.304 & 0.985 & 0.140 & 0.005 & -0.029 & 0.788 \\
\hline 1997 & 197 & 749 & -0.039 & -2.272 & 0.012 & 1.217 & 0.953 & 0.118 & 0.020 & -0.019 & 0.894 \\
\hline 1998 & 232 & 868 & -0.036 & -2.271 & 0.012 & 1.295 & 0.992 & 0.110 & 0.020 & -0.018 & 0.892 \\
\hline
\end{tabular}


On average, innovation-active firms show higher productivity levels than non-innovating ones. Firms engaged in product innovation have a higher average TFP level. Contrary to other findings in the literature, process innovation does not seem to have a similar significant effect on productivity. Variability of TFP levels for innovating and non-innovating groups does not reveal any recognizable pattern, especially in the case of process innovation. The results for the Kolmogorov-Smirnov two-sided and one-sided tests show that the null hypothesis of equal distributions can be rejected for product innovators. Moreover, lower productivity levels are observed in the group of non-innovators. Process innovation does not seem to have a differential effect on productivity levels of innovators relative to non-innovators.

In Table $2 C-D$, the results for the innovation and $R \& D$ variables are presented. Again, on average, innovating firms show higher TFP levels compared to firms in the non-innovating group. The comparison of average TFP levels indicates that firms engaged in innovation have higher total factor productivity levels. These firms also show lower variability in TFP. Kolmogorov-Smirnov one-sided and two-sided tests show that the null hypothesis of equal distributions can be rejected and lower productivity levels are observed in the group of firms with no innovation.

\subsection{Exporters Versus Non- Exporters Conditional on Innovation}

Finally, we conduct the tests for the subsamples of exporters and non-exporters accounting for firm innovation status. The results of the tests are listed in Tables $3 \mathrm{~A}-\mathrm{E}$.

\section{Exporters Versus Non- Exporters Conditional on Firm Innovation Status}

\section{Table 3A}

Differences in TFP Level Distributions Between Exporters and Non-Exporters Conditional on Firm Innovation Status. Product Innovation

\begin{tabular}{|c|c|c|c|c|c|c|c|c|c|c|c|}
\hline \multicolumn{12}{|c|}{ Product innovation $=1$} \\
\hline & \multicolumn{2}{|c|}{$\begin{array}{l}\text { Number of } \\
\text { firms }\end{array}$} & \multirow[t]{2}{*}{$\begin{array}{l}\text { Diffe- } \\
\text { rence } \\
\text { in } \\
\text { means }\end{array}$} & \multicolumn{2}{|c|}{$\begin{array}{c}\text { Mean (non- } \\
\text { exporters)> } \\
\text { mean (exporters) }\end{array}$} & \multicolumn{2}{|c|}{$\begin{array}{c}\text { Variance } \\
\text { (exporters)> } \\
\text { variance (non- } \\
\text { exporters) }\end{array}$} & \multicolumn{2}{|c|}{$\begin{array}{l}\text { K-S test for } \\
\text { equality of } \\
\text { distributions }\end{array}$} & \multicolumn{2}{|c|}{$\begin{array}{l}\text { Difference in } \\
\text { favor of } \\
\text { exporters }\end{array}$} \\
\hline & $\exp =1$ & $\exp =0$ & & t-statistic & $\mathrm{P}$-value & F-statistic & $P$-value & $\mathrm{D}$ & $\mathrm{P}$-value & $\mathrm{D}$ & $\mathrm{P}$-value \\
\hline 1991 & 27 & 33 & 0.096 & 1.863 & 0.966 & 3.105 & 0.997 & 0.319 & 0.060 & -0.319 & 0.048 \\
\hline 1992 & 57 & 33 & 0.011 & 0.265 & 0.604 & 0.915 & 0.401 & 0.148 & 0.670 & -0.148 & 0.399 \\
\hline 1993 & 58 & 40 & -0.024 & -0.631 & 0.264 & 1.437 & 0.895 & 0.132 & 0.740 & -0.132 & 0.439 \\
\hline 1994 & 67 & 42 & -0.028 & -0.732 & 0.232 & 0.952 & 0.440 & 0.114 & 0.845 & -0.064 & 0.808 \\
\hline 1995 & 68 & 32 & -0.036 & -0.822 & 0.206 & 1.260 & 0.787 & 0.159 & 0.546 & -0.093 & 0.682 \\
\hline 1996 & 74 & 35 & -0.063 & -1.493 & 0.069 & 1.253 & 0.791 & 0.234 & 0.101 & -0.057 & 0.854 \\
\hline 1997 & 76 & 27 & 0.003 & 0.068 & 0.527 & 1.394 & 0.865 & 0.126 & 0.864 & -0.099 & 0.672 \\
\hline 1998 & 85 & 36 & -0.100 & -2.623 & 0.004 & 0.585 & 0.039 & 0.285 & 0.020 & -0.031 & 0.952 \\
\hline & & & & & & & & & & & \\
\hline
\end{tabular}




\section{Table 3B}

Differences in TFP Level Distributions Between Exporters and Non-Exporters Conditional on Firm Innovation Status. Process Innovation

\begin{tabular}{|c|c|c|c|c|c|c|c|c|c|c|c|}
\hline \multicolumn{12}{|c|}{ Process innovation=1 } \\
\hline & & & $\begin{array}{l}\text { Diffe- } \\
\text { rence } \\
\text { in } \\
\text { means }\end{array}$ & $\begin{array}{r}\text { Mean } \\
\text { expor } \\
\text { mean (e }\end{array}$ & $\begin{array}{l}\text { lon- } \\
\text { rs)> } \\
\text { orters) }\end{array}$ & $\begin{array}{r}\text { Varianc } \\
\text { exporters) } \\
\text { (expo }\end{array}$ & $\begin{array}{l}\text { (non- } \\
\text { Iariance } \\
\text { ers) }\end{array}$ & $\begin{array}{l}\text { K-S } \\
\text { equ } \\
\text { distr }\end{array}$ & $\begin{array}{l}\text { st for } \\
\text { ity of } \\
\text { utions }\end{array}$ & $\begin{array}{r}\text { Diffe } \\
\text { fa } \\
\exp \end{array}$ & $\begin{array}{l}\text { nce in } \\
\text { rof } \\
\text { ters }\end{array}$ \\
\hline & $\exp =1$ & $\exp =0$ & & t-statistic & P-value & F-statistic & P-value & $D$ & $\mathrm{P}$-value & D & P-value \\
\hline 1991 & 16 & 25 & 0.030 & 0.457 & 0.675 & 1.651 & 0.842 & 0.240 & 0.517 & -0.240 & 0.325 \\
\hline 1992 & 65 & 100 & -0.027 & -0.801 & 0.212 & 0.734 & 0.083 & 0.103 & 0.734 & -0.031 & 0.928 \\
\hline 1993 & 86 & 57 & -0.032 & -1.037 & 0.150 & 0.917 & 0.355 & 0.118 & 0.651 & -0.065 & 0.745 \\
\hline 1994 & 73 & 86 & -0.028 & -0.863 & 0.194 & 0.958 & 0.424 & 0.108 & 0.687 & -0.063 & 0.729 \\
\hline 1995 & 73 & 79 & -0.075 & -1.988 & 0.024 & 1.117 & 0.682 & 0.182 & 0.120 & -0.014 & 0.984 \\
\hline 1996 & 69 & 81 & -0.022 & -0.642 & 0.260 & 0.748 & 0.110 & 0.096 & 0.842 & -0.043 & 0.869 \\
\hline 1997 & 80 & 71 & -0.052 & -1.691 & 0.046 & 1.271 & 0.850 & 0.163 & 0.212 & -0.014 & 0.985 \\
\hline 1998 & 112 & 93 & -0.105 & -3.074 & 0.001 & 1.512 & 0.981 & 0.244 & 0.003 & 0.000 & 1.000 \\
\hline
\end{tabular}

\section{Table 3C}

Differences in TFP Level Distributions Between Exporters and Non-Exporters Conditional on Firm Innovation Status. Innovation (Product and/or Process)

\begin{tabular}{|c|c|c|c|c|c|c|c|c|c|c|c|}
\hline \multicolumn{12}{|c|}{ Innovation=1 } \\
\hline & \multicolumn{2}{|c|}{$\begin{array}{c}\text { Number of } \\
\text { firms }\end{array}$} & \multirow[t]{2}{*}{$\begin{array}{l}\text { Diffe- } \\
\text { rence } \\
\text { in } \\
\text { means }\end{array}$} & \multicolumn{2}{|c|}{$\begin{array}{c}\text { Mean (non- } \\
\text { exporters)> } \\
\text { mean (exporters) }\end{array}$} & \multicolumn{2}{|c|}{$\begin{array}{c}\text { Variance (non- } \\
\text { exporters) }>\text { variance } \\
\text { (exporters) }\end{array}$} & \multicolumn{2}{|c|}{$\begin{array}{l}\text { K-S test for } \\
\text { equality of } \\
\text { distributions }\end{array}$} & \multicolumn{2}{|c|}{$\begin{array}{l}\text { Difference in } \\
\text { favor of } \\
\text { exporters }\end{array}$} \\
\hline & $\exp =1$ & $\exp =0$ & & t-statistic & P-value & F-statistic & P-value & $\mathrm{D}$ & P-value & $\mathrm{D}$ & P-value \\
\hline 1991 & 77 & 83 & 0.030 & 0.997 & 0.840 & 2.102 & 0.999 & 0.167 & 0.165 & -0.167 & 0.106 \\
\hline 1992 & 191 & 181 & -0.030 & -1.419 & 0.078 & 0.919 & 0.284 & 0.082 & 0.504 & -0.008 & 0.988 \\
\hline 1993 & 179 & 169 & -0.032 & -1.620 & 0.053 & 1.148 & 0.819 & 0.068 & 0.774 & -0.006 & 0.992 \\
\hline 1994 & 212 & 160 & -0.032 & -1.571 & 0.058 & 0.925 & 0.304 & 0.079 & 0.560 & -0.014 & 0.964 \\
\hline 1995 & 214 & 147 & -0.059 & -2.565 & 0.005 & 1.206 & 0.893 & 0.133 & 0.071 & -0.006 & 0.993 \\
\hline 1996 & 218 & 133 & -0.037 & -1.606 & 0.054 & 0.783 & 0.062 & 0.128 & 0.103 & -0.013 & 0.969 \\
\hline 1997 & 212 & 130 & -0.022 & -1.010 & 0.156 & 1.060 & 0.649 & 0.119 & 0.167 & -0.015 & 0.963 \\
\hline 1998 & 278 & 165 & -0.086 & -4.063 & 0.000 & 1.302 & 0.972 & 0.178 & 0.002 & 0.000 & 1.000 \\
\hline
\end{tabular}

\section{Table 3D}

Differences in TFP Level Distributions Between Exporters and Non-Exporters Conditional on Firm Innovation Status. No- Innovation Case

\begin{tabular}{|c|c|c|c|c|c|c|c|c|c|c|c|}
\hline \multicolumn{12}{|c|}{ No-innovation case } \\
\hline & \multicolumn{2}{|c|}{$\begin{array}{l}\text { Number of } \\
\text { firms }\end{array}$} & \multirow[t]{2}{*}{$\begin{array}{c}\text { Diffe- } \\
\text { rence } \\
\text { in } \\
\text { means }\end{array}$} & \multicolumn{2}{|c|}{$\begin{array}{c}\text { Mean (non- } \\
\text { exporters)> } \\
\text { mean (exporters) }\end{array}$} & \multicolumn{2}{|c|}{$\begin{array}{c}\text { Variance (non- } \\
\text { exporters)> variance } \\
\text { (exporters) }\end{array}$} & \multicolumn{2}{|c|}{$\begin{array}{l}\text { K-S test for } \\
\text { equality of } \\
\text { distributions }\end{array}$} & \multicolumn{2}{|c|}{$\begin{array}{l}\text { Difference in } \\
\text { favor of } \\
\text { exporters }\end{array}$} \\
\hline & $\exp =1$ & $\exp =0$ & & t-statistic & P-value & F-statistic & $\mathrm{P}$-value & $\mathrm{D}$ & $\mathrm{P}$-value & $\mathrm{D}$ & P-value \\
\hline & & & & & & & & & & & \\
\hline 1991 & 213 & 476 & -0.007 & -0.423 & 0.336 & 1.014 & 0.542 & 0.065 & 0.507 & -0.020 & 0.886 \\
\hline 1992 & 181 & 407 & -0.024 & -1.151 & 0.125 & 1.526 & 0.999 & 0.120 & 0.042 & -0.065 & 0.345 \\
\hline 1993 & 177 & 381 & -0.067 & -3.527 & 0.000 & 1.644 & 0.999 & 0.148 & 0.007 & -0.030 & 0.801 \\
\hline 1994 & 196 & 398 & -0.048 & -2.581 & 0.005 & 1.011 & 0.530 & 0.157 & 0.002 & -0.007 & 0.984 \\
\hline 1995 & 231 & 357 & -0.056 & -3.079 & 0.001 & 0.972 & 0.403 & 0.165 & 0.001 & -0.003 & 0.997 \\
\hline 1996 & 221 & 338 & -0.073 & -3.826 & 0.000 & 1.164 & 0.889 & 0.201 & 0.000 & -0.011 & 0.967 \\
\hline 1997 & 275 & 330 & -0.076 & -4.178 & 0.000 & 0.948 & 0.322 & 0.184 & 0.000 & -0.003 & 0.997 \\
\hline 1998 & 295 & 362 & -0.046 & -2.743 & 0.003 & 1.555 & 1.000 & 0.129 & 0.006 & -0.008 & 0.978 \\
\hline
\end{tabular}




\section{Table 3E}

Differences in TFP Level Distributions Between Exporters and Non-Exporters Conditional on Firm R\&D Status

\begin{tabular}{|c|c|c|c|c|c|c|c|c|c|c|c|}
\hline \multicolumn{12}{|c|}{$R \& D=1$} \\
\hline & \multicolumn{2}{|c|}{$\begin{array}{c}\text { Number of } \\
\text { firms }\end{array}$} & \multirow[t]{2}{*}{$\begin{array}{l}\text { Diffe- } \\
\text { rence } \\
\text { in } \\
\text { means }\end{array}$} & \multicolumn{2}{|c|}{$\begin{array}{c}\text { Mean (non- } \\
\text { exporters)> } \\
\text { mean (exporters) }\end{array}$} & \multicolumn{2}{|c|}{$\begin{array}{c}\text { Variance (non- } \\
\text { exporters)> } \\
\text { variance (exporters) }\end{array}$} & \multicolumn{2}{|c|}{$\begin{array}{l}\text { K-S test for } \\
\text { equality of } \\
\text { distributions }\end{array}$} & \multicolumn{2}{|c|}{$\begin{array}{l}\text { Difference in } \\
\text { favor of } \\
\text { exporters }\end{array}$} \\
\hline & $\exp =1$ & $\exp =0$ & & t-statistic & $P$-value & F-statistic & $P$-value & $\mathrm{D}$ & $P$-value & $\mathrm{D}$ & P-value \\
\hline & & & & & & & & & & & \\
\hline 1991 & 100 & 44 & -0.001 & -0.015 & 0.493 & 1.284 & 0.845 & 0.130 & 0.597 & -0.060 & 0.797 \\
\hline 1992 & 137 & 61 & -0.006 & -0.226 & 0.410 & 0.980 & 0.475 & 0.056 & 0.999 & -0.048 & 0.819 \\
\hline 1993 & 133 & 52 & -0.0310 & -1.085 & 0.139 & 1.702 & 0.991 & 0.178 & 0.140 & -0.072 & 0.678 \\
\hline 1994 & 143 & 63 & -0.047 & -1.512 & 0.065 & 0.9 & 0.486 & 0.125 & 0.431 & -0.027 & 0.938 \\
\hline 1995 & 159 & 45 & 8 & -1.787 & 0.037 & 1.494 & 0.961 & 0.176 & 0.173 & -0.038 & 0.903 \\
\hline 1996 & 138 & 43 & -0.077 & -2.291 & 0.011 & 0.584 & 0.023 & 0.281 & 0.006 & -0.029 & 0.946 \\
\hline 1997 & 147 & 50 & -0.045 & -1.384 & 0.083 & 1.143 & 0.731 & 0.153 & & -0.033 & 0.921 \\
\hline \multirow[t]{2}{*}{1998} & 174 & 58 & -0.066 & -2.279 & 0.011 & 0.996 & 0.508 & 0.2011 & 0.041 & -0.005 & 0.997 \\
\hline & & & & & & & & & & & \\
\hline \multicolumn{12}{|c|}{$R \& D=0$} \\
\hline & \multicolumn{2}{|c|}{$\begin{array}{l}\text { Number of } \\
\text { firms }\end{array}$} & $\begin{array}{l}\text { Diffe- } \\
\text { rence } \\
\text { of } \\
\text { means }\end{array}$ & \multicolumn{2}{|c|}{$\begin{array}{c}\text { Mean (non- } \\
\text { exporters)> } \\
\text { mean (exporters) }\end{array}$} & \multicolumn{2}{|c|}{$\begin{array}{l}\text { Variance (non- } \\
\text { exporters)> } \\
\text { variance } \\
\text { (exporters) }\end{array}$} & \multicolumn{2}{|c|}{$\begin{array}{l}\text { K-S test for } \\
\text { equality of } \\
\text { distributions }\end{array}$} & \multicolumn{2}{|c|}{$\begin{array}{l}\text { Difference in } \\
\text { favor of } \\
\text { exporters }\end{array}$} \\
\hline & $\exp =1$ & $\exp =0$ & & t-statistic & $P$-value & F-statistic & P-value & $\mathrm{D}$ & P-value & $\mathrm{D}$ & $P$-value \\
\hline 1991 & 190 & 515 & 004 & 0.230 & 0.590 & 1.175 & 0.904 & 0.033 & 0.997 & -0.033 & 0.731 \\
\hline 1992 & 235 & 527 & $\begin{array}{l}0.004 \\
-0.027\end{array}$ & -1.551 & 0.060 & 1.279 & 0.984 & 0.090 & 0.118 & -0.033 & 0.700 \\
\hline 1993 & 223 & 498 & -0.056 & -3.344 & 0.000 & 1.303 & 0.988 & 0.110 & 0.037 & -0.001 & 1.000 \\
\hline 1994 & 265 & 495 & -0.039 & -2.459 & 0.007 & 1.019 & 0.565 & 0.128 & 0.005 & -0.010 & 0.964 \\
\hline 1995 & 286 & 459 & 56 & -3.411 & 0.000 & 0.923 & 0.224 & 0.135 & 0.002 & -0.000 & 1.000 \\
\hline 1996 & 302 & 427 & -0.052 & -3.138 & 0.000 & 1.037 & 0.632 & 0.149 & 0.001 & -0.006 & 0.983 \\
\hline 1997 & 340 & 409 & -0.058 & -3.631 & 0.000 & 0.965 & 0.367 & 0.156 & 0.000 & -0.001 & 0.999 \\
\hline 1998 & 399 & 469 & -0.059 & -3.968 & 0.000 & 1.451 & 0.999 & 0.140 & 0.000 & -0.003 & 0.993 \\
\hline & & & & & & & & & & & \\
\hline
\end{tabular}

In line with our hypothesis, we find that innovating exporters do not differ significantly in their productivity levels from innovating non-exporters. Kolmogorov-Smirnov test statistics support these findings - we cannot reject the null hypothesis of equal distributions in the group of innovators, although exporting innovators still show higher productivity levels.

For the non-innovating group, however, the results are drastically different. We observe a significant difference in TFP levels for exporters and non-exporters. The tests indicate that exporting firms outperform non-exporting ones with respect to TFP showing significantly higher levels of productivity. Moreover, the two-sided Kolmogorov-Smirnov test statistic rejects the hypothesis of equality of distributions.

\subsection{Quantile regression results}

To get a more complete picture of the way productivity is linked to exports we use quantile regressions. More specifically, we regress the TFP variable on the export dummy and control variables including foreign capital ownership, high-tech sector and year dummies. We also test the association between the TFP level and innovation activity, regressing TFP on innovation variables. 
The association between export/innovation status and productivity may vary at different points of the conditional distribution of productivity levels, and a quantile regression provides information on this variation. For each quantile, it can be shown whether the association between exports/innovation and productivity is positive, negative or insignificant, and how strong it is compared to other quantiles.

Table 4A-C presents the regression estimates of the export/innovation variables for OLS regression and five different quantiles of the TFP level distribution for 1991-1998.

\section{Quantile Regression Results, 1991-19985}

\section{Table 4A}

Estimated Results of TFP Levels for the Export/Innovation Dummy Variables, 1991-1998

\begin{tabular}{|c|c|c|c|c|c|c|}
\hline \multicolumn{7}{|c|}{ Dependent variable: TFP level } \\
\hline \multicolumn{7}{|c|}{ Reported coefficient: Export (0/1) } \\
\hline & OLS & & & uantile re & & \\
\hline \multirow[t]{2}{*}{ Export $(0 / 1)$} & & $5 \%$ & $25 \%$ & $50 \%$ & $75 \%$ & $95 \%$ \\
\hline & $\begin{array}{l}0.044^{* \star \star} \\
(0.008)\end{array}$ & $\begin{array}{l}0.084^{\star \star \star} \\
(0.012)\end{array}$ & $\begin{array}{l}0.052^{\star \star \star} \\
(0.005)\end{array}$ & $\begin{array}{l}0.033^{\star \star \star} \\
(0.004)\end{array}$ & $\begin{array}{l}0.018^{\star \star \star} \\
(0.005)\end{array}$ & $\begin{array}{l}0.043^{\star \star \star} \\
(0.013)\end{array}$ \\
\hline
\end{tabular}

\section{Table 4B}

Estimated Results of TFP Levels for the Innovation Variables, 1991-1998

\begin{tabular}{|c|c|c|c|c|c|c|}
\hline \multicolumn{7}{|c|}{ Dependent variable: TFP level } \\
\hline \multicolumn{7}{|c|}{ Reported coefficient: Product innovation (0/1) } \\
\hline & OLS & & & uantile re & & \\
\hline \multirow{2}{*}{$\begin{array}{l}\text { Product } \\
\text { innovation } \\
(0 / 1)\end{array}$} & & $5 \%$ & $25 \%$ & $50 \%$ & $75 \%$ & $95 \%$ \\
\hline & $\begin{array}{l}0.032^{* * *} \\
(0.009)\end{array}$ & $\begin{array}{l}0.057^{\star \star} \\
(0.022)\end{array}$ & $\begin{array}{l}0.045^{\star \star \star} \\
(0.009)\end{array}$ & $\begin{array}{l}0.019^{\star \star \star} \\
(0.007)\end{array}$ & $\begin{array}{l}0.011 \\
(0.009)\end{array}$ & $\begin{array}{l}0.032 \\
(0.025)\end{array}$ \\
\hline
\end{tabular}

\begin{tabular}{|l|l|l|l|l|l|l|}
\hline \multicolumn{6}{|l|}{ Dependent variable: TFP level } \\
\hline \multicolumn{7}{|l|}{ Reported coefficient: Process innovation (0/1) } \\
\hline & OLS & \multicolumn{5}{|c|}{ Quantile regression } \\
\hline $\begin{array}{l}\text { Process } \\
\text { innovation } \\
(0 / 1)\end{array}$ & & $5 \%$ & $25 \%$ & $50 \%$ & $75 \%$ & $95 \%$ \\
\hline & & & & & & \\
& 0.003 & -0.005 & 0.010 & 0.000 & 0.006 & -0.018 \\
& $(0.007)$ & $(0.021)$ & $(0.007)$ & $(0.007)$ & $(0.006)$ & $(0.019)$ \\
\hline
\end{tabular}

\footnotetext{
${ }^{5}$ Standard errors are given in brackets. Foreign capital and high-tech industry dummy are included as covariates. Year fixed effects are included. *, **, *** are significantly different from zero at the $10 \%, 5 \%$ or $1 \%$ level, respectively.
} 


\begin{tabular}{|c|c|c|c|c|c|c|}
\hline \multicolumn{7}{|c|}{ Dependent variable: TFP level } \\
\hline \multicolumn{7}{|c|}{ Reported coefficient: Innovation (0/1) } \\
\hline & OLS & & & uantile re & & \\
\hline \multirow{2}{*}{$\begin{array}{l}\text { Process } \\
\text { innovation } \\
(0 / 1) \\
\end{array}$} & & $5 \%$ & $25 \%$ & $50 \%$ & $75 \%$ & $95 \%$ \\
\hline & $\begin{array}{l}0.018^{\star \star *} \\
(0.005)\end{array}$ & $\begin{array}{l}0.035^{\star \star} \\
(0.015)\end{array}$ & $\begin{array}{l}0.029^{\star \star \star} \\
(0.006)\end{array}$ & $\begin{array}{l}0.017^{\star \star \star} \\
(0.005)\end{array}$ & $\begin{array}{l}0.011^{\star \star} \\
(0.004)\end{array}$ & $\begin{array}{l}-0.004 \\
(0.014)\end{array}$ \\
\hline
\end{tabular}

\begin{tabular}{|l|l|l|l|l|l|l|}
\hline \multicolumn{6}{|l|}{ Dependent variable: TFP level } \\
\hline Reported coefficient: RD (0/1) \\
\hline & OLS & \multicolumn{5}{|c|}{ Quantile regression } \\
\hline $\mathrm{RD}(0 / 1)$ & & $5 \%$ & $25 \%$ & $50 \%$ & $75 \%$ & $95 \%$ \\
\hline & $0.025^{\star \star \star}$ & $\mathbf{0 . 0 5 0 ^ { \star \star \star }}$ & $\mathbf{0 . 0 3 5 ^ { \star \star \star }}$ & $\mathbf{0 . 0 2 8 ^ { \star \star \star }}$ & $\mathbf{0 . 0 1 9 ^ { \star \star \star }}$ & -0.014 \\
& $(0.007)$ & $\mathbf{( 0 . 0 1 3 )}$ & $\mathbf{( 0 . 0 0 4 )}$ & $\mathbf{( 0 . 0 0 4 )}$ & $\mathbf{( 0 . 0 0 5 )}$ & $0(.012)$ \\
\hline
\end{tabular}

\section{Table 4C}

Estimated Results of TFP Levels for the Export Dummy Variable Conditional on Firm Innovation Status, 1991- 1998

\begin{tabular}{|c|c|c|c|c|c|c|}
\hline \multicolumn{7}{|c|}{ Product innovation $=1$} \\
\hline \multicolumn{7}{|c|}{ Dependent variable: TFP level } \\
\hline \multicolumn{7}{|c|}{ Reported coefficient: Export (0/1) } \\
\hline & OLS & & & uantile $r$ & & \\
\hline \multirow[t]{2}{*}{ Export $(0 / 1)$} & & $5 \%$ & $25 \%$ & $50 \%$ & $75 \%$ & $95 \%$ \\
\hline & $\begin{array}{l}0.017 \\
(0.018)\end{array}$ & $\begin{array}{l}0.041 \\
(0.049)\end{array}$ & $\begin{array}{l}0.025 \\
(0.016)\end{array}$ & $\begin{array}{l}-0.002 \\
(0.014)\end{array}$ & $\begin{array}{l}0.000 \\
(0.014)\end{array}$ & $\begin{array}{l}0.043 \\
(0.057)\end{array}$ \\
\hline
\end{tabular}

\begin{tabular}{|l|l|l|l|l|l|l|}
\hline \multicolumn{7}{|l|}{ Process innovation=1 } \\
\hline Dependent variable: TFP level \\
\hline \multicolumn{7}{|l|}{ Reported coefficient: Export (0/1) } \\
\hline & OLS & & $25 \%$ & $50 \%$ & $75 \%$ & $95 \%$ \\
\hline Export (0/1) & & $5 \%$ & $\mathbf{0 . 0 3 4}^{\star}$ & $\mathbf{0 . 0 3 5 ^ { \star \star \star }}$ & 0.013 & $\mathbf{0 . 0 7 6 ^ { \star \star \star }}$ \\
\hline & $0.044^{\star \star \star}$ & $\mathbf{0 . 0 9 7 ^ { \star \star \star }}$ & $\mathbf{( 0 . 0 1 3 )}$ & $(0.018)$ & $\mathbf{( 0 . 0 2 7 )}$ \\
& $(0.017)$ & $(\mathbf{0 . 0 3 2})$ & $\mathbf{( 0 . 0 1 9 )}$ & &
\end{tabular}

\begin{tabular}{|c|c|c|c|c|c|c|}
\hline \multicolumn{7}{|c|}{ Innovation=1 } \\
\hline \multicolumn{7}{|c|}{ Dependent variable: TFP level } \\
\hline \multicolumn{7}{|c|}{ Reported coefficient: Export (0/1) } \\
\hline & OLS & & & dantile reg & & \\
\hline \multirow[t]{2}{*}{ Export (0/1) } & & $5 \%$ & $25 \%$ & $50 \%$ & $75 \%$ & $95 \%$ \\
\hline & $\begin{array}{l}0.035^{\star \star \star} \\
(0.012)\end{array}$ & $\begin{array}{l}0.084^{\star \star \star} \\
(0.016)\end{array}$ & $\begin{array}{l}0.024^{\star \star \star} \\
(0.009)\end{array}$ & $\begin{array}{l}0.026^{\star \star \star} \\
(0.008)\end{array}$ & $\begin{array}{l}0.009 \\
(0.010) \\
\end{array}$ & $\begin{array}{l}0.074^{\star \star \star} \\
(0.022)\end{array}$ \\
\hline
\end{tabular}

\begin{tabular}{|c|c|c|c|c|c|c|}
\hline \multicolumn{7}{|c|}{ No-innovation case } \\
\hline \multicolumn{7}{|c|}{ Dependent variable: TFP level } \\
\hline \multicolumn{7}{|c|}{ Reported coefficient: Export (0/1) } \\
\hline & OLS & & & uantile re & & \\
\hline \multirow[t]{2}{*}{ Export $(0 / 1)$} & & $5 \%$ & $25 \%$ & $50 \%$ & $75 \%$ & $95 \%$ \\
\hline & $\begin{array}{l}0.042^{\star \star \star} \\
(0.010)\end{array}$ & $\begin{array}{l}0.070^{\star \star \star} \\
(0.018)\end{array}$ & $\begin{array}{l}0.053^{\star \star \star} \\
(0.008)\end{array}$ & $\begin{array}{l}0.035^{\star \star \star} \\
(0.006)\end{array}$ & $\begin{array}{l}0.017^{\star \star} \\
(0.007)\end{array}$ & $\begin{array}{l}0.021 \\
(0.019)\end{array}$ \\
\hline
\end{tabular}




\begin{tabular}{|c|c|c|c|c|c|c|}
\hline \multicolumn{7}{|l|}{$R \& D=0$} \\
\hline \multicolumn{7}{|c|}{ Dependent variable: TFP level } \\
\hline \multicolumn{7}{|c|}{ Reported coefficient: Export (0/1) } \\
\hline & OLS & \multicolumn{5}{|c|}{ Quantile regression } \\
\hline \multirow[t]{2}{*}{ Export $(0 / 1)$} & & $5 \%$ & $25 \%$ & $50 \%$ & $75 \%$ & $95 \%$ \\
\hline & $\begin{array}{l}0.040^{* * *} \\
(0.010)\end{array}$ & $\begin{array}{l}0.073^{\star \star \star} \\
(0.015)\end{array}$ & $\begin{array}{l}0.046^{\star \star \star} \\
(0.006)\end{array}$ & $\begin{array}{l}0.030^{\star \star \star} \\
(0.006)\end{array}$ & $\begin{array}{l}0.012^{\star \star} \\
(0.005)\end{array}$ & $\begin{array}{l}0.052^{\star \star \star} \\
(0.016)\end{array}$ \\
\hline \multicolumn{7}{|l|}{$R \& D=1$} \\
\hline \multicolumn{7}{|c|}{ Dependent variable: TFP level } \\
\hline \multicolumn{7}{|c|}{ Reported coefficient: Export (0/1) } \\
\hline & OLS & & & dantile re & & \\
\hline \multirow[t]{2}{*}{ Export $(0 / 1)$} & & $5 \%$ & $25 \%$ & $50 \%$ & $75 \%$ & $95 \%$ \\
\hline & $\begin{array}{l}0.038^{\star *} \\
(0.018)\end{array}$ & $\begin{array}{l}0.111^{\star \star \star} \\
(0.036)\end{array}$ & $\begin{array}{l}0.041^{\star \star \star} \\
(0.015)\end{array}$ & $\begin{array}{l}0.027^{\star \star} \\
(0.011)\end{array}$ & $\begin{array}{l}0.014 \\
(0.015)\end{array}$ & $\begin{array}{l}0.029 \\
(0.028)\end{array}$ \\
\hline
\end{tabular}

We find that the significance and the magnitude of the export coefficient vary considerably as we move from the lower quantile (0.05) to the upper quantile (0.95) of the conditional productivity distribution. The association between productivity and exports seems to be strengthened in the lower tail and the center of the distribution but weakened towards the upper tail, suggesting that among the most productive firms, exporters and non-exporters tend to vary less in their productivity levels. With respect to the innovation variables, the results support our previous finding that product innovation is associated with the higher productivity, while process innovation comes out insignificant.

Accounting for firms' innovation status, in the group of non-innovators we find a positive and significant association between exports and the productivity level. The positive correlation between the export variable and productivity remains significant for the firms engaged in process innovation. For the firms performing product innovation, however, the export coefficient is insignificant along the entire productivity distribution, suggesting the importance of the effect of product innovation in explaining the export-productivity link. Thus, the results show that it is mainly product innovation that accounts for the differences in the productivity levels and consequently leads firms to export.

\section{Discussion}

In this paper, we examine the relationship between exports, productivity, and innovation at the firm level. Our findings highlight that the positive link between exports and productivity differs considerably depending on the firm's innovation strategy. We do not observe significant differences in productivity levels between exporters and non-exporters among firms that carry out product innovation. Once we take into account the innovation strategy, firm productivity comes out to be independent of whether or not a firm participates in exports.

However, the positive link between exports and productivity observed in prior research does exist for non-innovating firms, consistent with the learning-by-exporting effect emphasized by recent studies. The observed superior efficiency among exporting firms in the low and middleproductivity range may be related to their ability to get new technological information on the export markets and to the higher competition abroad. For the most productive firms, however, the positive association between exports and productivity is found to be weaker, suggesting 
that for these firms the learning-by-exporting effect might not be strong enough to affect their initial productivity levels.

Our results suggest that innovation, and more specifically product innovation, allows firms to enter the export market. Successful product innovation enhances the firm's productivity leading to the selection of the more productive firm into the export markets. This finding appears to be especially relevant from a public policy perspective. If innovation activity is a source of productivity growth, then policies aimed at promoting innovation, and product innovation in particular, might be more effective than direct export promotions, at least for firms "at risk" for innovating.

There remain several issues to address. More specifically, we would like to look at the evolution of firms over time comparing different groups of firms, such as "always" exporting firms, nonexporting firms, firms entering in and exiting from export markets. We will focus on the subsample of non-innovating firms, thus isolating the effect of innovation, while testing for the selection versus learning hypothesis in the productivity-export link.

\section{Exporting Versus Non-Exporting Firms}

\section{Figure 1}

Cumulative Distribution of TFP Levels. Exporters Versus Non-Exporters, 1991-1998

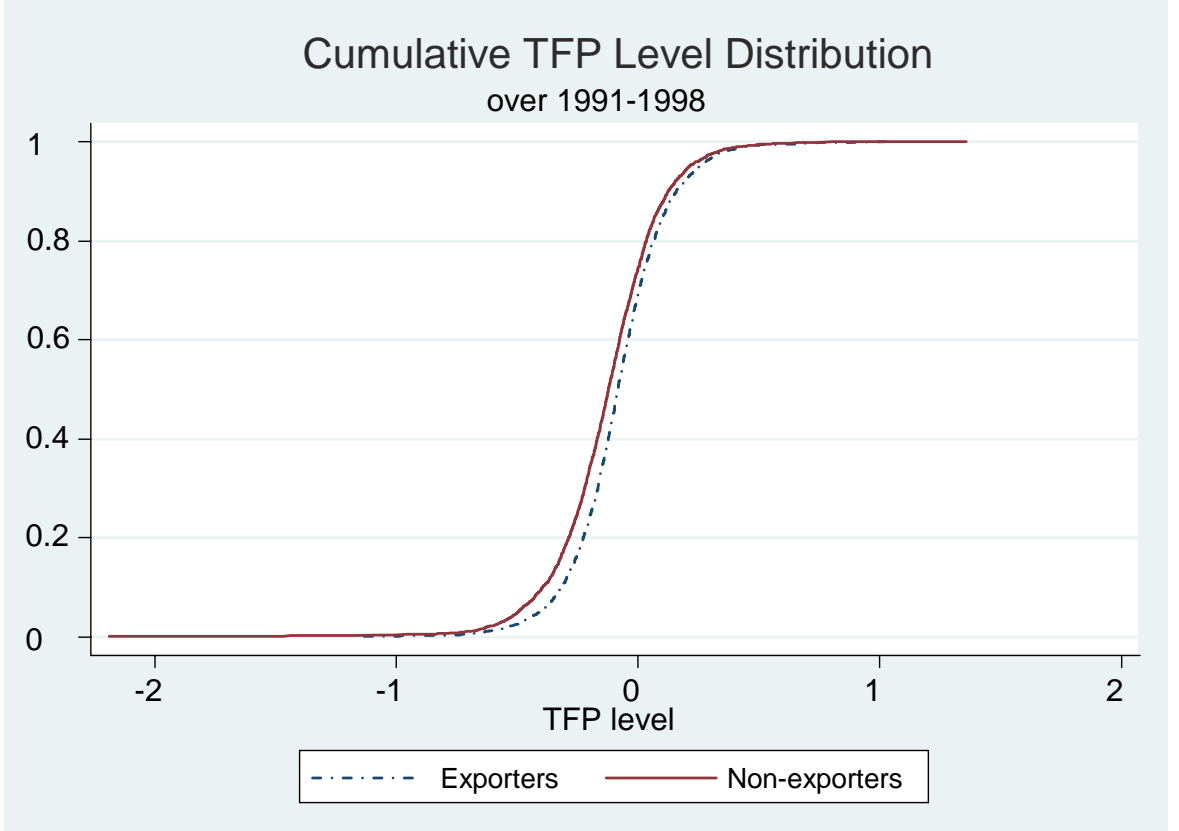




\section{Innovating Versus Non-Innovating Firms}

\section{Figure 2}

Cumulative Distribution of TFP Levels. Firms with Product Innovation Versus Firms with No Innovation, 1991-1998

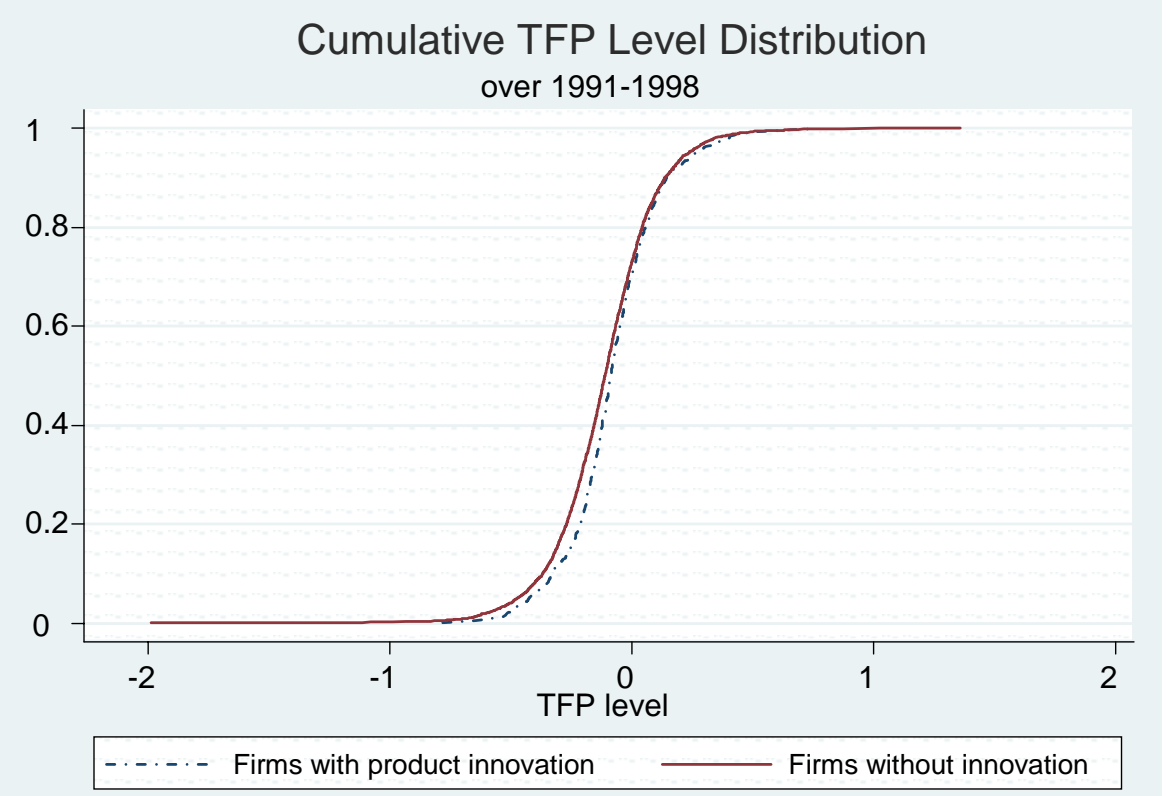

\section{Figure 3}

Cumulative Distribution of TFP Levels. Firms with Process Innovation Versus Firms with No Innovation, 1991-1998

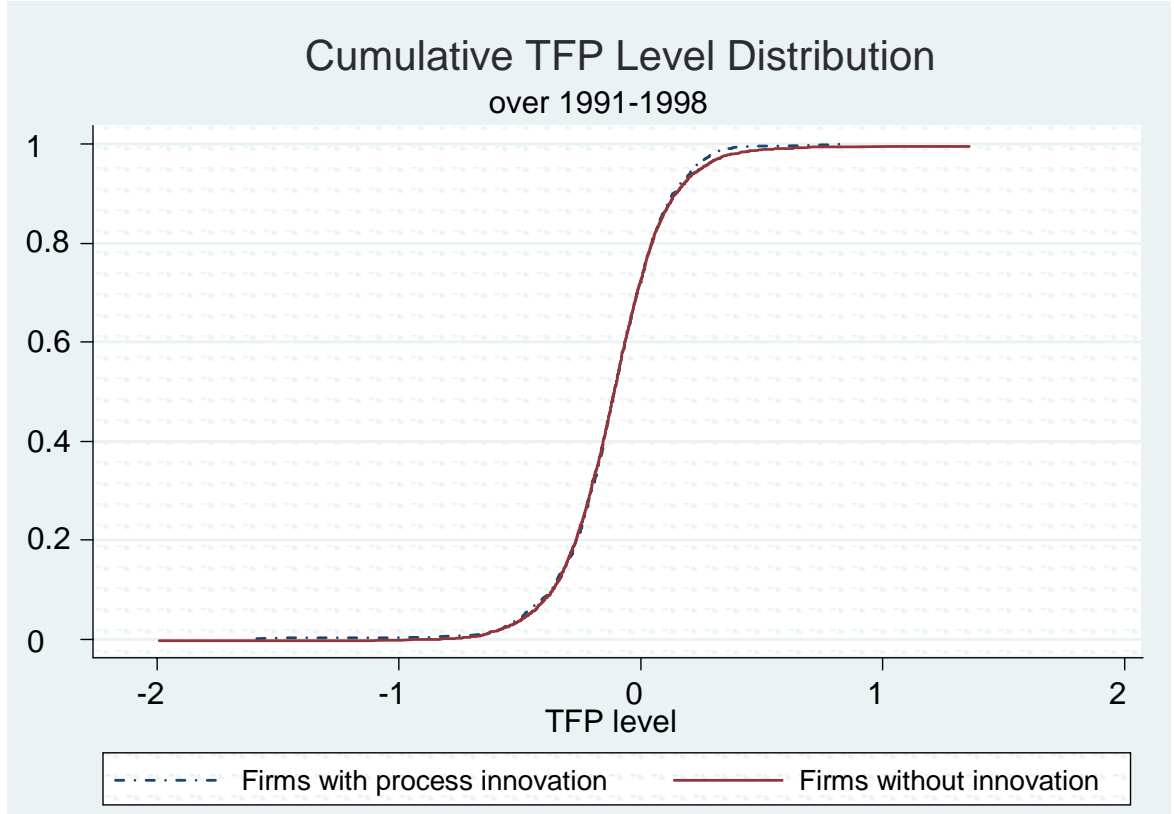




\section{Figure 4}

Cumulative Distribution of TFP Levels. Firms with Innovation Versus Firms with No Innovation, 1991-1998

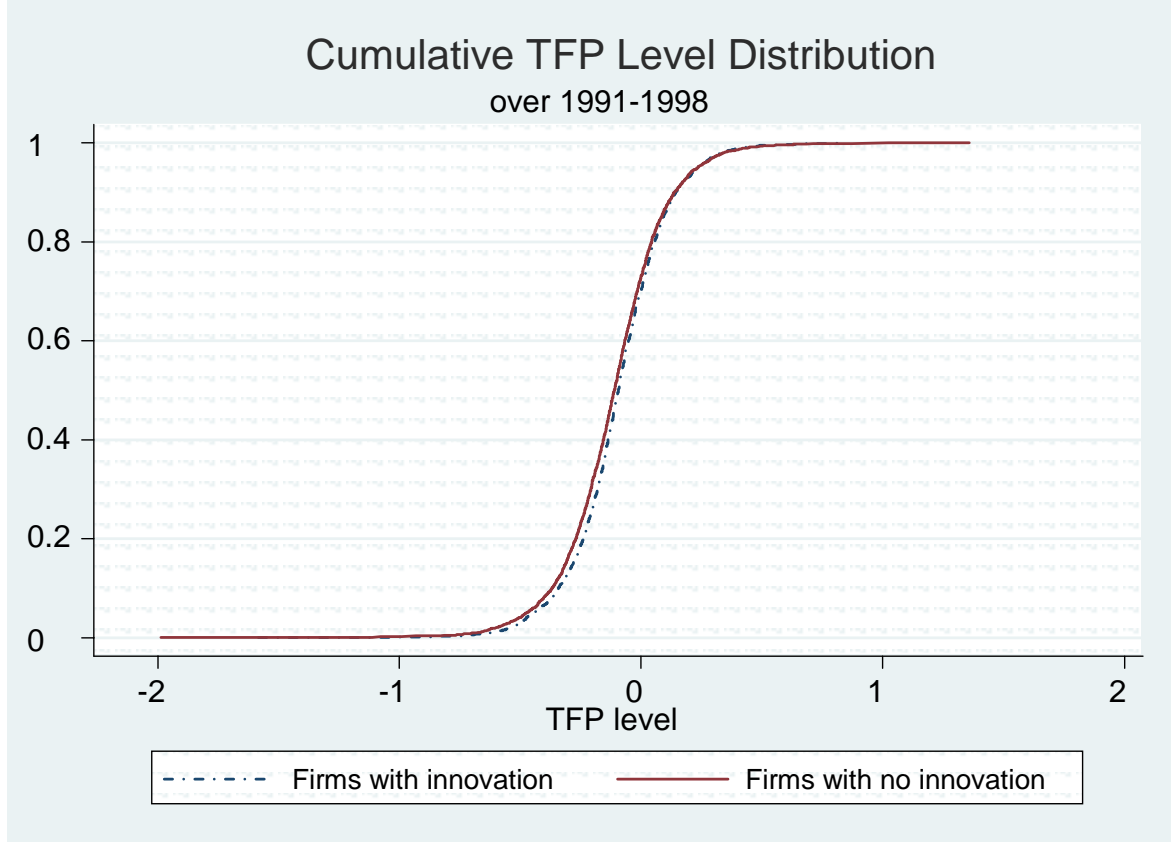

\section{Figure 5}

Cumulative Distribution of TFP Levels. Firms with R\&D Versus Firms without R\&D, 1991-1998

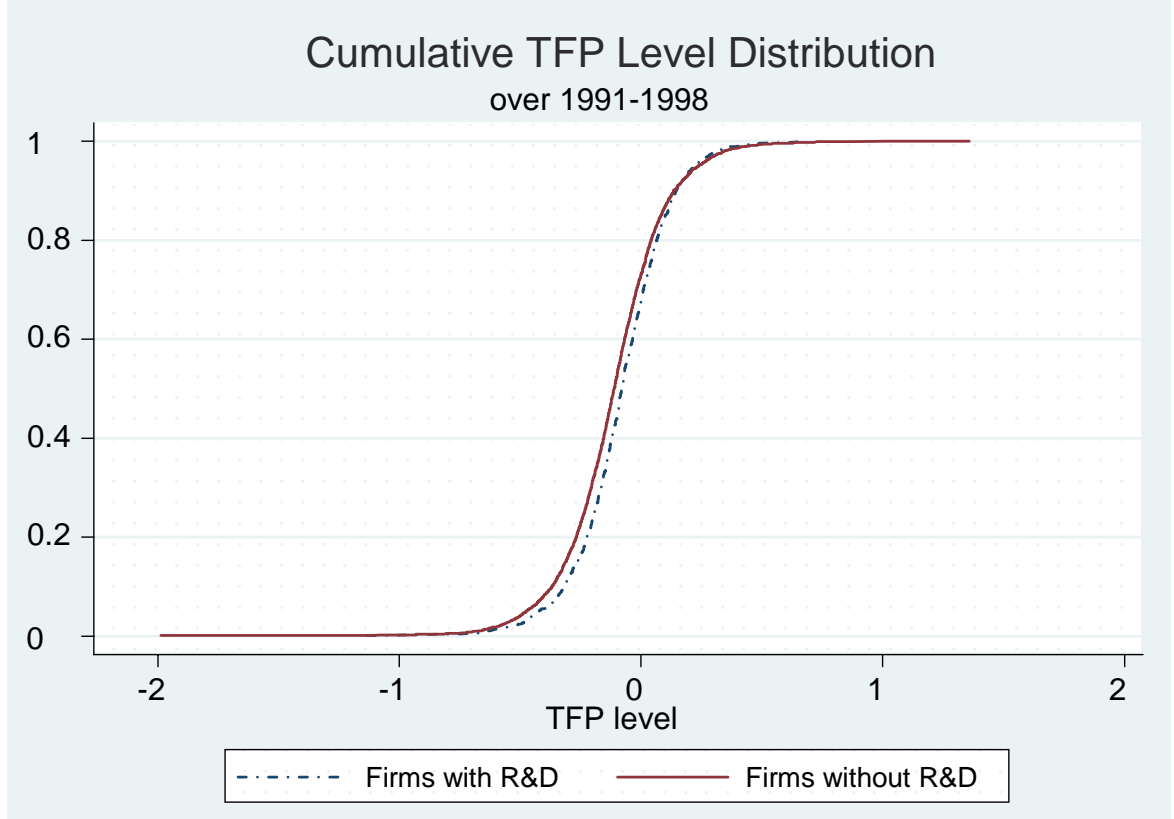




\section{Exporting Versus Non-Exporting Firms Conditional on Innovation Status}

\section{Figure 6}

Cumulative Distribution of TFP Levels. Exporters Versus Non-Exporters, for Firms with Product Innovation and without Innovation, 1991-1998

Product innovation $=1$

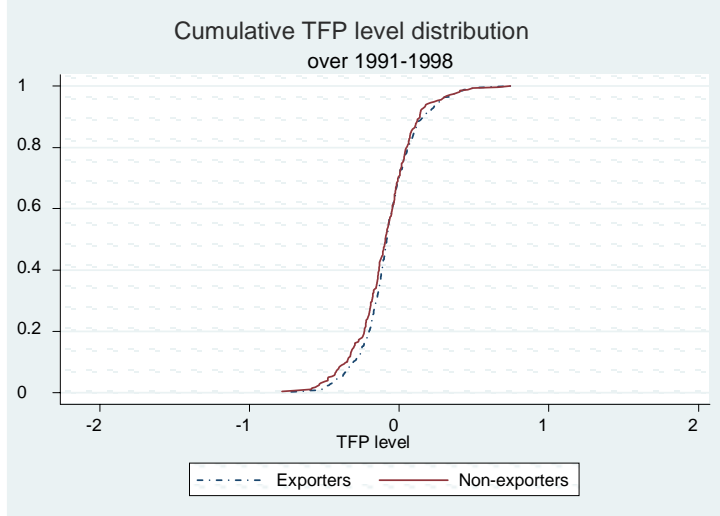

No-innovation case

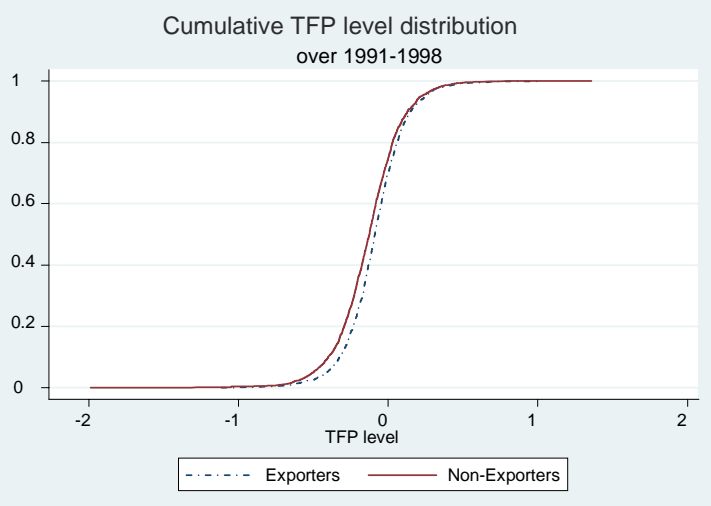

\section{Figure 7}

Cumulative Distribution of TFP Levels. Exporters Versus Non-Exporters, for Firms with Process Innovation and without Innovation, 1991-1998

Process innovation $=1$

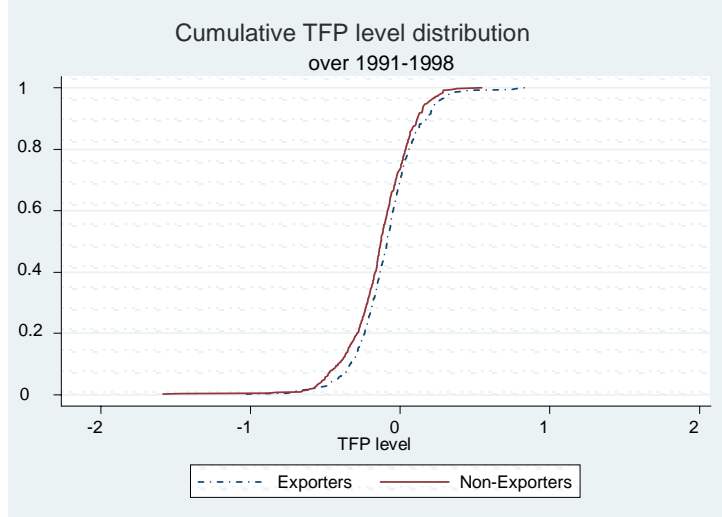

No-innovation case

Cumulative TFP level distribution over 1991-1998

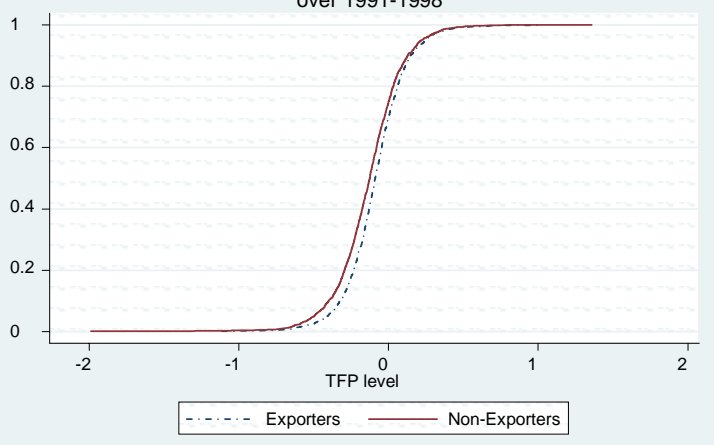

\section{Figure 8}

Cumulative Distribution of TFP Levels. Exporters Versus Non-Exporters, for Firms with Innovation and without Innovation, 1991-1998

Innovation $=1$

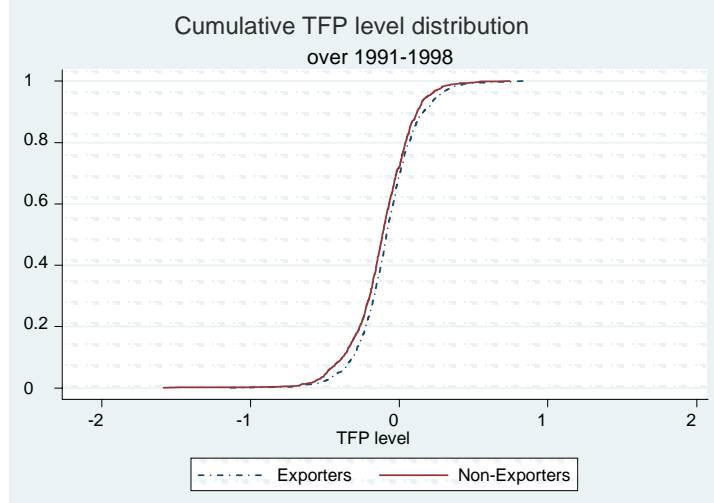

No-innovation case

Cumulative TFP level distribution over 1991-1998

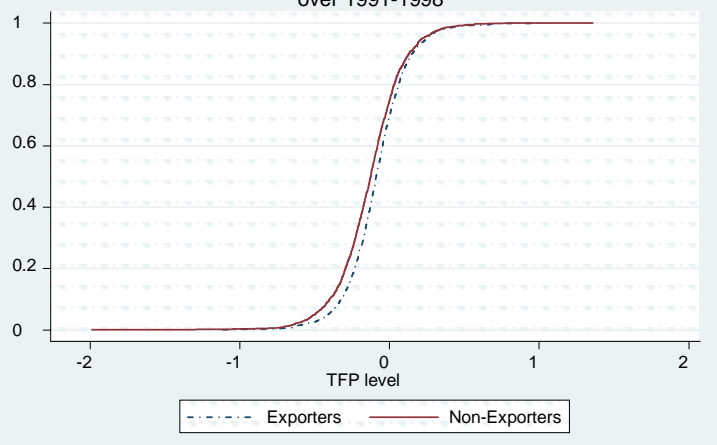




\section{Figure 9}

Cumulative Ddistribution of TFP Levels. Exporters Versus Non-Exporters, for Firms with R\&D and without R\&D, 1991-1998

$R \& D=1$

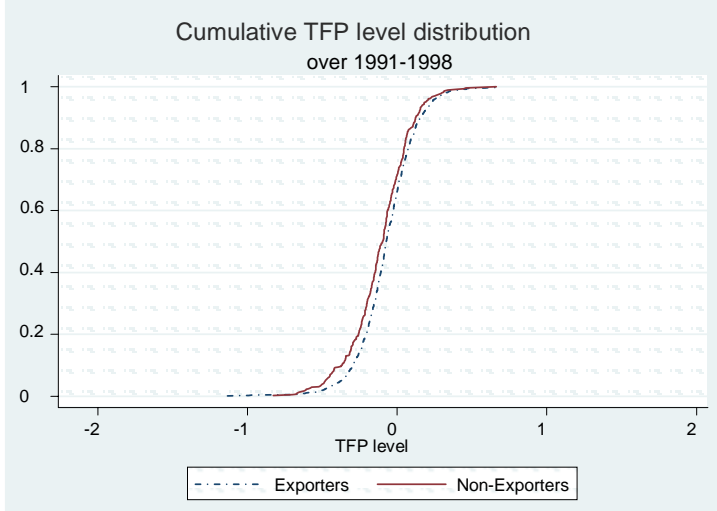

$R \& D=0$

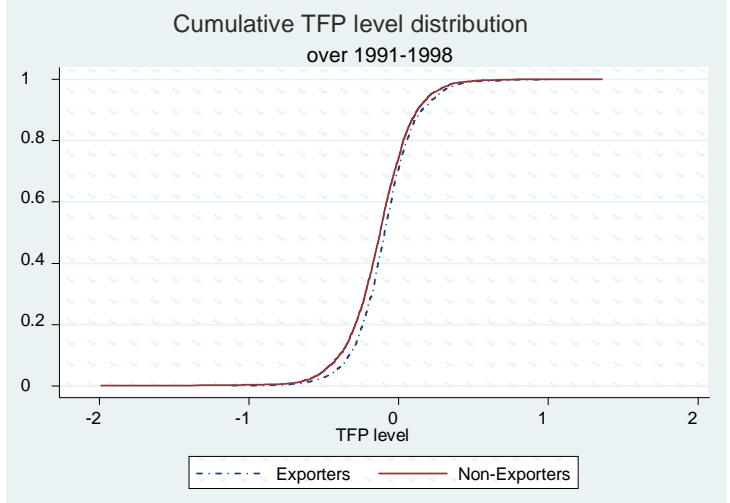




\section{References}

Aw, B. Y. and G. Batra (1998), "Technology, exports and firm efficiency in Taiwanese manufacturing," Economics of Innovation \& New Technology, 7, (2).

Aw, B.Y., X. Chen, and M. J. Roberts (1997), "Firm-level Evidence on Productivity Differentials, Turnover, and Exports in Taiwanese Manufacturing," Pennsylvania State University, mimeo.

Aw, B. Y., S. Chung, and M. Roberts (2000), "Productivity and the turnover in the export market: Micro-level evidence for the Republic of Korea and Taiwan (China)," The World Bank Economic Review, 14, pp. 313-332.

Aw, B.Y., M. Roberts, and T. Winston (2005), "The Complementary Role of Exports and R\&D Investments as Sources of Productivity Growth," Working Paper 11774, http://www.nber.org/papers/w11774

Barrios, S., H. Gorg, et al. (2003), "Explaining Firms' Export behaviour: R\&D, Spillovers and the Destination Market," Oxford Bulletin of Economics \& Statistics, 65, (4).

Bartelsman, E.J . and M. Doms (2000), "Understanding Productivity: Lessons from Longitudinal Microdata," J ournal of Economic Literature, 38, 3.

Basile, R. (2001), "Export behaviour of Italian manufacturing firms over the nineties: the role of innovation," Research Policy, 30 (8), pp. 1185-1201.

Bernard, A.B. and J.B. Jensen (1999), "Exceptional exporter performance: cause, effect or both?," J ournal of International Economics, 47, pp. 1-25.

Bernard A., J. Eaton, J. J ensen, and S. Kortum (2003), "Plants and Productivity in International Trade," American Economic Review, 93, 4, pp. 1268-1290.

Bernard, A.B. and J.B. Jensen (2004), "Why some firms export," The Review of Economics and Statistics, 86 (2).

Campa, J.M. (2004), "Exchange Rates and Trade: How Important is Hysteresis in Trade?," European Economic Review, 48, (3), pp. 527-548.

Cassiman, B. and E. Martínez-Ros (2007), "Product Innovation and Exports: Evidence from Spanish Manufacturing," IESE working paper, mimeo.

Caves, D.W., L. Christensen, and E. Diewert (1982), "Output, Input, and Productivity Using Superlative Index Numbers," Economic J ournal, 92, pp. 73-96.

Clerides, S.K., S. Lach, et al. (1998), "Is learning by exporting important? Micro-dynamic evidence from Colombia, Mexico, and Morocco," The Quarterly Journal of Economics, 113 (3).

Crepon, B., E. Duguet, and J. Mairesse (1998), "Research and Development, Innovation and Productivity: An Econometric Analysis at the Firm Level," Economics of Innovation and New Technology, 7 (2), pp. 115-158.

Delgado, M.A., J.C. Farinas, et al. (2002), "Firm productivity and export markets: a nonparametric approach," J ournal of International Economics, 57 (2), pp. 397-422. 
Duguet, E. (2000), "Knowledge diffusion, innovation and TFP growth at the firm level: evidence from French Manufacturing," University of Paris I, Cahiers de la MSE, EUREQua 2000, 105.

Fafchamps, M., S. El Hamine, et al. (2002), "Learning to Export: Evidence from Moroccan Manufacturing," CSAE Working Paper Series.

Foster, L., J . Haltiwanger, and C. Syverson (2005), "Reallocation, Firm Turnover, and Efficiency: Selection on Productivity or Profitability?," mimeo.

Good, D.H., M.I. Nadiri, and R. Sickles (1997), "Index Number and Factor Demand Approaches to the Estimation of Productivity," in M. Pesaran and P. Schmidt (eds.), "Handbook of Applied Econometrics," Vol II: "Microeconometrics," Basil Blackwell.

Griffith, R., E. Huergo, J. Mairesse, and B. Peeters (2005), "Innovation and productivity across four European countries," presented at EARIE conference, Porto.

Hopenhayn, H. (1992), "Entry, Exit and Firm Dynamics in Long Run Equilibrium," Econometrica, 60, (5), pp. 1127-1150.

Huergo E. and J . J aumandreu (2004), "Firms' age, process innovation and productivity growth," International J ournal of Industrial Organization, 22, pp. 541-559.

Jefferson, G., B. Huamao, G. Xiaojing, and Y. Xiayung (2002), "R\&D performance in Chinese industry," Working paper, proceedings of the NBER Productivity workshop.

Jovanovic, B. (1982), "Selection and the Evolution of Industry," Econometrica, 50, (3), pp. 649-670.

Melitz, M. (2003), "The Impact of Trade on Intra-industry Reallocations and Aggregate Industry Productivity," Econometrica, 71, (6), pp. 1695-1725.

Pakes, A. and R. Ericson (1995), "Markov Perfect Industry Dynamics: A Framework for Empirical work," Review of Economic Studies, 62, (1), pp. 53-82.

Roberts, M.J . and J.R. Tybout (1997), "The Decision to Export in Colombia: An Empirical Model of Entry with Sunk Costs," A merican Economic Review, 87 (4), pp. 545-564. 


\section{Appendix 1}

Variable definitions

\begin{tabular}{|c|c|}
\hline Variable & Description \\
\hline TFP level & $\begin{array}{l}\text { Firm-specific index of total factor productivity constructed using a multilateral index (the detailed } \\
\text { explanation on its calculation is provided further in Appendix)) }\end{array}$ \\
\hline Export & $\begin{array}{l}\text { Export status dummy, equal to } 1 \text { if firm exports at time } t \text { and } 0 \text { if it performs no exporting activities at } \\
\text { time } t\end{array}$ \\
\hline Innovation: & \\
\hline 1) $R \& D$ investment & - Dummy variable equal to 1 if firm invested in $R \& D$ at time $t-1$ \\
\hline $\begin{array}{l}\text { 2) Product } \\
\text { innovation dummy }\end{array}$ & $\begin{array}{l}\text { - Dummy variable equal to } 1 \text { if firm carried out product innovation only at time t-1;0 - if firm } \\
\text { performed neither product nor process innovation at time t-1 }\end{array}$ \\
\hline $\begin{array}{l}\text { 3) Process } \\
\text { innovation dummy }\end{array}$ & $\begin{array}{l}\text { - Dummy variable equal to } 1 \text { if firm carried out process innovation only at time } t-1 ; 0-\text { if firm } \\
\text { performed neither product nor process innovation at time t-1 }\end{array}$ \\
\hline 4) Innovation dummy & $\begin{array}{l}\text { - Dummy variable equal to } 1 \text { if firm carried out either product or process innovation at time } \mathrm{t}-1 \text {; } \\
0-\text { if firm performed neither product nor process innovation at time } \mathrm{t}-1\end{array}$ \\
\hline Foreign capital & Foreign capital dummy, equal to 1 if firm has more than $50 \%$ of foreign capital at time $t$ \\
\hline High-tech & Dummy variable, equal to 1 if firm belongs to high-tech sector \\
\hline
\end{tabular}

\section{Definition of Product and Process Innovation in the ESEE Survey}

\section{Product Innovation:}

- Whether a firm obtained product innovation in a given year - new products, or products with new features that are different from those that a firm produced in the previous years. If the answer is yes, the type of modification is asked:

- incorporates new materials

- incorporates new components or intermediate products

- incorporates new design or presentation

- the product performs new functions

\section{Process Innovation:}

- Whether a firm introduced an important modification in the production process. If the answer is yes, the type of modification is asked:

- introduction of new machinery

- introduction of new methods of production organization

- both

\section{Calculation of the TFP Index}

The TFP index measures the proportional difference in TFP for a firm $i$ from size group $s$ in year $t$ relative to a hypothetical reference firm in the same industry $r$. We consider two size groups, determined by the ESEE survey. A firm belongs to a group of large firms if the number 
of workers it employs is more than 200; and to a group of small firms if the number of employees is less than or equal to 200.

The reference firm is defined as follows:

- the output is equal to the geometric mean of outputs over all observations in industry $r$;

- inputs are equal to the geometric means of inputs over all observations in industry $r$;

- cost shares are the arithmetic means of cost shares over all observations in industry $r$.

The total factor productivity index for firm i $(i=1, \ldots, N)$ from industry $\mathrm{r}(r=1, \ldots, R)$ and size group $\mathrm{s}$ in year $\mathrm{t}(t=1, \ldots, T)$ is computed using the following formula:

$$
\begin{aligned}
\ln T F P_{i t}=\ln Y_{i t} & -\overline{\ln Y_{s r}}-\sum_{j=1}^{J} \frac{1}{2}\left(S_{i t j}+\overline{S_{s r j}}\right)\left(\ln X_{i t j}-\overline{\ln X_{s r j}}\right)+ \\
+ & \overline{\ln Y_{s r}}-\overline{\ln Y_{r}}-\sum_{j=1}^{1} \frac{1}{2}\left(\overline{S_{s r j}}+\overline{S_{r j}}\right)\left(\overline{\ln X_{s r j}}-\overline{\ln X_{r j}}\right)^{\prime}
\end{aligned}
$$

where $Y_{i t}$ is an output of firm i in year t, $X_{i t j}$ is an input $\mathrm{j}(j=\overline{1, J})$ of firm i in year t, and $S_{i t j}$ is a cost-based share of input j of firm i in year t; and $\overline{\ln Y_{s r}}=\frac{1}{N T} \sum_{i=1}^{N} \sum_{t=1}^{T} \ln Y_{i t s r}$, $\overline{\ln Y_{r}}=\frac{1}{N T} \sum_{i=1}^{N} \sum_{t=1}^{T} \ln Y_{i t r}, \overline{\ln X_{s r}}=\frac{1}{N T} \sum_{i=1}^{N} \sum_{t=1}^{T} \ln X_{i t s r}, \overline{\ln X_{r}}=\frac{1}{N T} \sum_{i=1}^{N} \sum_{t=1}^{T} \ln X_{i t r}$, and $\overline{S_{s r}}=\frac{1}{N T} \sum_{i=1}^{N} \sum_{t=1}^{T} S_{i t s r}, \overline{S_{r}}=\frac{1}{N T} \sum_{i=1}^{N} \sum_{t=1}^{T} S_{i t r}$ are the same variables for the reference firm.

The ESEE data provide information on the output and input variables needed to measure total factor productivity at the firm level. We model each firm as using three inputs in its production function: labor, capital and material input. The labor input is measured as the number of total effective working hours per year. The measure of capital input is the capital stock, calculated using the following formula: $k_{t}^{*}=I_{t}+k_{t-1}^{*}\left(1-d_{t}\right) \frac{P_{t}}{P_{t-1}}$, where I represents investment in equipment in year $t, d$ - depreciation rates in year t, $P$ - price indexes for equipment in year $t^{6}$ The material input includes raw materials, fuel and electricity costs, and other services bought by a firm. The material expenditures are deflated using the firm specific price indexes for each of the inputs provided in the ESEE survey. Firm output is defined as total firm sales corrected by inflation.

Cost-based input shares are calculated as the costs of each input in total input costs. The total input cost is the sum of the labor cost, material cost and the cost of capital. Labor costs are

\footnotetext{
${ }^{6}$ The information on depreciation rates and price indexes for equipment is provided by the Instituto Nacional de Estadística (www.ine.es).
} 
measured as total salaries to employees deflated by the consumer price index. Capital cost is computed using an estimation of the user cost of capital for each firm.

User cost of capital is calculated as the sum of the cost of long-term debt and depreciation rates less the variation of the price index for capital goods. The cost share of materials is calculated as the residual after subtracting the expenditures on labor and capital. 